\title{
Working
}

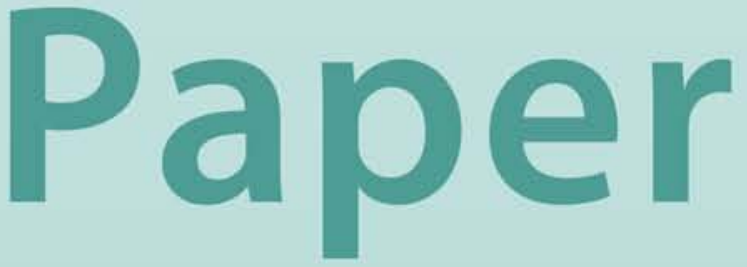


$\mathrm{WP} / 02 / 53$

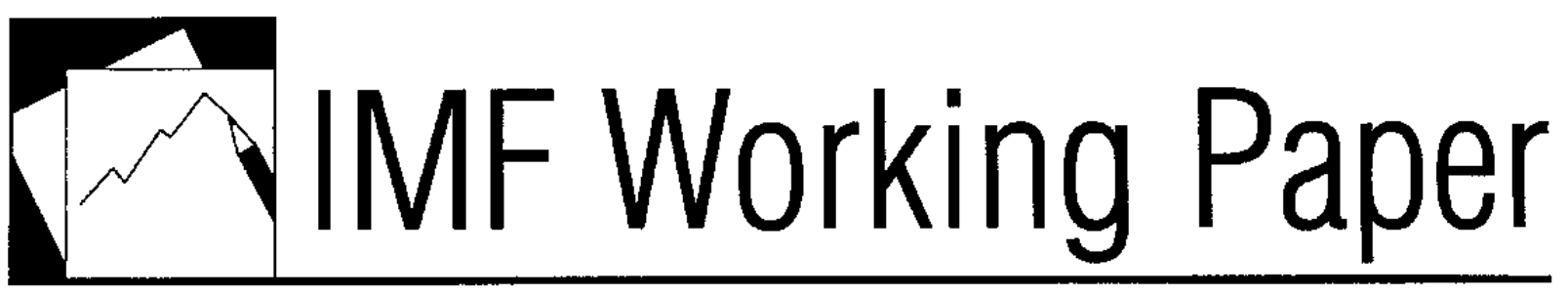

\section{Credit Stagnation in Latin America}

Adolfo Barajas and Roberto Steiner 


\title{
IMF Working Paper
}

IMF Institute

\section{Credit Stagnation in Latin America}

\author{
Prepared by Adolfo Barajas and Roberto Steiner ${ }^{1}$ \\ Authorized for distribution by Enzo Croce
}

March 2002

\begin{abstract}
The views expressed in this Working Paper are those of the author(s) and do not necessarily represent those of the IMF or IMF policy. Working Papers describe research in progress by the author(s) and are published to elicit comments and to further debate.
\end{abstract}

This study examines the recent marked slowdown in bank credit to the private sector in Latin America. Based on the study of eight countries (Argentina, Bolivia, Brazil, Chile, Colombia, Peru, Mexico, and Venezuela), the magnitude of the slowdown is documented, comparing it to historical behavior and to slowdown episodes in other regions of the world. Second, changes in bank balance sheets are examined to determine whether the credit slowdown is merely a reflection of a slowdown in bank deposits, or whether the asset side has changed. Third, following an econometric disequilibrium approach used in recent studies of credit slowdowns in East Asia and Finland, the paper investigates possible causes for the slowdown in three countries: Colombia, Mexico, and Peru. While both supply and demand factors appear to have played key roles, their relative importance has varied across countries.

JEL Classification Number: G21

Keywords: credit, banking system, Latin America.

Author’s E-Mail Address: abarajas@imf.org,rsteiner@uniandes.edu.co

${ }^{1}$ Roberto Steiner is at Universidad de los Andes in Bogotá and was a Visiting Scholar at the IMF Institute in July 2001. We would like to thank Atish Ghosh for providing his TSP disequilibrium estimation program, and thank seminar participants at the Institute, the LACEA 2001 Conference, the IMF 2nd Annual Research Conference, and the 2002 ASSA Meetings for their comments on earlier drafts. We have particularly benefited from comments by Alejandro Werner, Jerry Caprio, Ricardo Hausmann, Olver Bernal, José Dorich, and Fund economists working on countries in our sample. We alone are responsible for any remaining errors. 


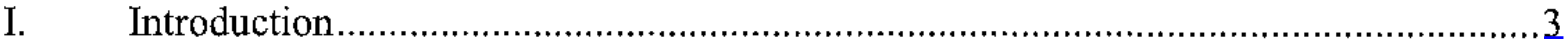

II. The "Credit Channel:" A Brief Survey of the Literaturc ............................................. 5

III. Credit Stagnation in Latin America: A First Look ................................................ 8

A. The Latin American Credit Slowdown in Historical and International

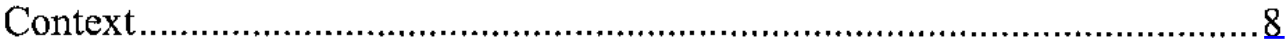

B. The Latin American Credit Slowdown-Some Stylized Facts.........................16

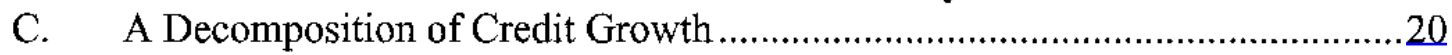

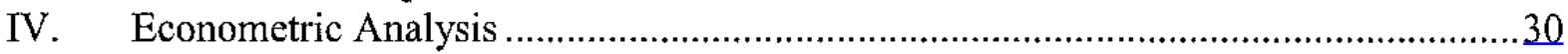

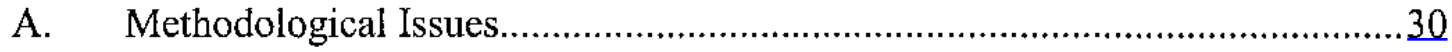

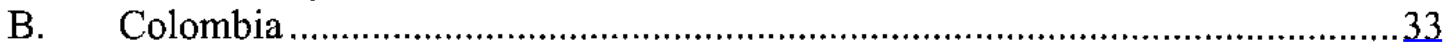

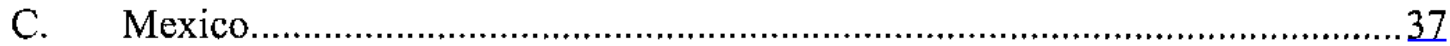

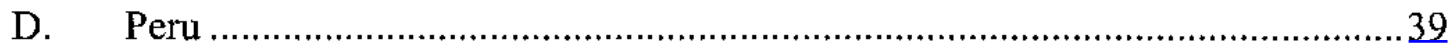

E. Decomposition of Estimated Changes in Credit ...........................................40

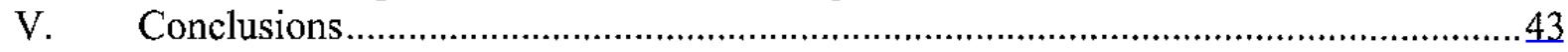

Figures

1. Credit-GDP Ratios in Latin America, 1960-2000 …….........................................

2. Latin America - Absolute Deviations in the Credit-GDP Ratio with Respect to Trend ...................................................................................12

3. Credit-GDP Ratios 1960-2000-Selected Cases of Credit Slowdown........................13

4. Absolute Deviations in the Credit-GDP Ratio with Respect to Trend-

Selected Cases of Credit Slowdown .................................................................14

5. Colombia. Credit and Capital Inflows ................................................................43

Tables

1. Average Real Growth Rates of GDP and Credit to the Private Sector ...........................3

2. Latin American Credit Slowdown in Historical Context.........................................15

3. Latin American Credit Slowdown in Comparison with Selected International Cases 17

4. The Recent Credit Slowdown in Latin America - A Summary ..................................18

4a. Earlier Credit Slowdown in Latin America-A Summary .......................................19

5. Decomposition of Credit Growth—Recent Cases of Slowdown.................................22

5a. Decomposition of Credit Growth: Earlier Cases of Slowdown ................................23

6. Components of Credit Growth-Differences with Respect to Previous Period...........25

6a. Components of Credit Growth-Differences with Respect to Precious Periods ........26

7. Major Factors Contributing to Changes in Credit Growth ........................................27

7a. Major Factors Contributing to Changes in Credit Growth .....................................28

8. Colombia. Credit Demand and Supply Estimations ..................................................34

9. Mexico. Credit Demand and Supply Estimations......................................................35

10. Peru. Credit Demand and Supply Estimations ......................................................36

11. Decomposition of Estimated Changes in Real Credit...............................................42

Appendix Tables

I. IFS Banking System Definitions ……….........................................................

II. Selected Latin American Counties: Private Sector Credit.......................................46

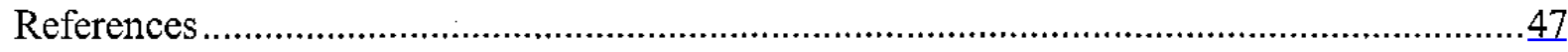




\section{INTRODUCTION}

After experiencing moderate to high rates of growth during most of the 1990s, several Latin American countries witnessed a significant slowdown in growth over the past two years. As Table 1 below illustrates, Argentina, Bolivia, Brazil, Chile, Colombia, Peru, and Venezuela all have recently experienced declines in their growth rates in recent years, declines which have ranged from about 1 percentage point in Brazil to 7 percentage points in Argentina. One prominent exception to this behavior is Mexico, for which economic growth accelerated by about 1 percentage point on average after 1995.

Table 1. Average Real Growth Rates of GDP and Credit to the Private Sector Selected Latin American Countries

\begin{tabular}{|c|c|c|c|c|}
\hline & \multicolumn{2}{|c|}{ GDP } & \multicolumn{2}{|c|}{$\begin{array}{c}\text { Deposit Money Banks } \\
\text { Credit to the Private Sector }\end{array}$} \\
\hline & 1992-98 & $1999-2000$ & $1992-98$ & $1999-2000$ \\
\hline Argentina & 5.0 & -2.0 & 10.9 & -2.3 \\
\hline Bolivia & 4.3 & 1.4 & 15.8 & -2.7 \\
\hline Brazil & 3.0 & 2.2 & 4.1 & -5.0 \\
\hline Chile & 7.7 & 2.1 & 11.4 & 6.5 \\
\hline Colombia & 3.8 & -0.7 & 13.1 & -10.0 \\
\hline Peru & 4.8 & 2.0 & 27.1 & -1.7 \\
\hline \multirow[t]{2}{*}{ Venezuela } & 2.0 & -1.5 & -7.7 & 0.6 \\
\hline & $1992-94$ & $1995-2000$ & $1992-94$ & $1995-2000$ \\
\hline Mexico & 2.5 & 3.5 & 19.6 & -14.6 \\
\hline
\end{tabular}

Source: IMF International Financial Statistics.

In many cases, the evolution of commercial bank credit to the private sector has followed a similar, and even more pronounced, cyclical pattern. When deflated by consumer prices, during the above periods credit growth decelerated by about 5 percentage points in Chile, by over 9 percentage points in Brazil, by 13 in Argentina and 18 percentage points in Bolivia, and by over 20 percentage points in Colombia and Peru. The Mexican and Venezuelan cases stand in contrast to the rest, however; in Mexico credit growth fell much more sharply than in the other countries, by over 34 percentage points, even as economic growth was accelerating; and in Venezuela economic growth declined while credit enjoyed a modest recovery.

In policy circles in several countries it is widely believed that the slowdown in financial sector credit is an important driving force behind the recent economic slump. According to some interpretations, growth will only be restored once the "credit channel" becomes operative once again. As the above figures suggest, this line of reasoning is challenged by the Mexican case, where two possible explanations have been offered for this apparent lack of a relationship between credit growth and economic activity. On the one hand, it has been pointed out that 
large Mexican corporations have ample access to foreign capital markets, thereby being able to invest and grow regardless of the fact that, following the 1994 "Tequila crisis," the Mexican financial system has been in very bad shape. A second interpretation has to do with accounting issues - while we observe a decline in credit when we look at bank's assets, corporations who have not repaid their credits or who have had access to several debt restructuring programs have not seen their effective financing curtailed.

Accounting issues aside, and given that in most Latin American countries only a very few large corporations can tap foreign capital markets, the recent slowdown in credit becomes a very relevant issue. ${ }^{2}$ In this paper we focus on the eight countries mentioned above, and try to identify, in a systematic manner, what are the factors that explain the evolution of bank credit to the private sector. It should be pointed out that the principal variable we examine is credit as reported in bank's balance sheets. However, in certain countries, and under certain conditions, it may not fully capture what is actually happening to the effective financing being received by households and firms. For this reason, in some cases we also consider an alternative definition of credit. ${ }^{3}$

The paper is divided into five sections, including this introduction. In the second section we provide a very brief analytical discussion of issues related to the "credit channel" and review some of the recent empirical literature. In the third section we take a first look at the data, following a very simple accounting framework. This will allow us to look at the recent credit slowdown episode both from a historical as well as from a comparative perspective. In the

\footnotetext{
${ }^{2}$ The credit slowdown will be of particular importance in countries where firms depend heavily on the financial system as a source of financing. While it is generally believed that in Latin America firms finance most of their investment with their own resources and that outside resources generally come from banks and not from the selling of equity, we have no access to reliable comparable data for the countries in our sample. A case study for Colombia (Steiner and Salazar, 1998) showed that in the first half of the 1990s financing of firms came from profit withholding (33 percent), new equity (12 percent) and loans ( 55 percent). However, it did not differentiate the origin of loans, in order to isolate those from financial institutions as opposed to other sources, such as suppliers. A more recent study (Arbelaez and Echavarria, 2002) indicates that in 1999 around 19 percent of manufacturing firm's liabilities were with financial institutions.
}

${ }^{3}$ As we discuss in Section IV, we use alternative definitions of credit in some of the econometric estimations for Colombia and Mexico. For Colombia, we use an adjusted stock of credit which accounts for loan write-offs, an issue that became increasingly relevant as a result of the crisis affecting savings and loan institutions in the late 1990s. As shown in Bajaras, Oliveros, and López (2001), during 1998-2000, this adjustment reduces the measured annual credit decline from almost 13 percent to about 7 percent for the total financial system. In the case of Mexico, we used a measure that accounted for the effect of credit restructuring programs beginning in late 1995. Although the fall in the adjusted series is much smaller than in the unadjusted IFS series during 1995-96, over the entire post crisis period (1995-2000) the decline is roughly similar for both series, averaging $12-14$ percent per year. 
fourth section we undertake the econometric analysis, and in the fifth section we present our conslusions.

\section{The "Credit Channel:" A Brief Survey OF The Literature}

In the textbook IS/LM model, in which bank loans are not distinguished from other assets in the bond market, monetary policy has real effects because (i) it affects the interest rate at which the money market clears; (ii) the change in the interest rate, in turn, affects private expenditure. Following the work of Bernanke and Blinder (1988), Romer and Romer (1990) and others, increasing attention has been devoted to the role of banks in the provision of credit. The socalled "credit channel" has become instrumental in understanding the link between monetary policy and overall economic activity.

Banks hold assets in the form of reserves (mandatory and/or "excess" reserves), loans and bonds. While the overall size of assets is determined by the provision of bank reserves on the part of the central bank and by the public's willingness to own bank deposits, the composition of assets is affected by several considerations, including the demand for loans from the corporate sector and the willingness of banks to satisfy that demand.

One would like to distinguish among three factors affecting the evolution of financial sector credit. On the one hand, there is the demand for credit from the corporate sector, which in turn can depend on several factors, including observed and expected economic activity. Regarding supply, it is critical to distinguish between a bank's ability to lend-which might be constrained by the level of deposits--and its willingness to do so-in turn, closely associated to its perception of risk.

Evidently, relevant policy implications as to how to address a credit contraction critically depend on a correct interpretation of the factors that explain a particular episode.

Interventions, if warranted, might range from programs to alleviate corporate debt burden, enhancing the provision of liquidity on the part of the central bank, or revising the regulatory framework regarding the level of provisions.

A vast empirical literature has recently emerged, trying to identify whether or not specific situations of credit contraction can be identified as being characterized by a "credit crunch," loosely defined as a situation in which, for a given level of deposits, bank's opt to purchase low-yielding securities (that is, government bonds) rather than to increase interest rates on their loans, in order to allow the credit market to clear, and thus, excess demand for credit remains unsatisfied. It is important to keep in mind that such a situation can emerge either because bank's perceptions of corporate risk are too high, or because they simply do not have enough capital to accommodate riskier loans.

One of the first empirical approximations to the "credit crunch" phenomenon was provided by Bernanke and Lown (1991). Using state-by-state data, they found support for the "credit crunch" hypothesis in the case of the United States. Specifically, they identified that bank's level of capital was actually restricting their ability to supply credit. 
More recently, Pazarbasioglu (1997) estimated a disequilibrium model of credit demand and supply for Finland, following Laffont and Garcia (1977), using monthly data for the 1981-1995 period. In particular reference to the sharp decline in bank lending following the banking crisis of 1991-92, this paper provides evidence that such a decline was not the result of a credit crunch but, rather, the reflection of a cyclical decline in credit demand, in turn associated with borrowers' high level of indebtedness.

A disequilibrium approach is also used by Ghosh and Ghosh (1999) to analyze the contraction of credit during the 1997-98 East Asian crisis in Indonesia, Korea, and Thailand. By including as an explanatory variable of credit supply bank's actual lending capacity, they are able to differentiate between the ability to lend and the willingness to do so. Their results suggest that while real credit supply to the private sector diminished, estimated demand declined even more sharply. In that sense, they find no evidence of a credit crunch. Cautiously, the authors do not preclude the possibility that a few creditworthy firms were in fact supply-constrained, something they obviously cannot capture when using aggregate data. ${ }^{4}$

Several papers offer a different interpretation of events in the aftermath of the East Asian crisis. For example, Agenor et al. (2000) develop and estimate a model according to which the contraction of bank lending in Thailand was basically the reflection of a supply phenomenon. Their model is based on a demand function for bank's excess reserves. The estimation of a dynamic version of the model indicates that excess reserves were rather modest. If the slowdown in credit had been the result of a reduction in the demand for loans, then there would have been an important "involuntary" accumulation of reserves.

With specific reference to the case of Korea, Kim (1999) uses different methodological approaches-including the estimation of a disequilibrium model of the bank loan market-and also reports evidence that the severe credit contraction following the Asian crisis was mainly driven by a sharp decline in credit supply. The excess demand for bank loans would have in turn originated in a stringent regulation regarding capital requirements, at a time when nonperforming loans were mounting.

In the Latin American context, a growing empirical literature on credit contractions has recently emerged. For example, in reference to the conditions of the credit market following the 1995 Mexican crisis, Catao (1997) estimates an aggregate model of credit supply and demand for Argentina, using monthly data for the June 1991-1996 period. He reports that

${ }^{4}$ To be sure, using aggregate data tends to obscure important differences, particularly in the corporate sector. In a paper of a descriptive nature, Krueger and Tornell (1998) argue that in the case of Mexico it is important to differentiate between large export-oriented firms that have relatively good access to international financial markets from firms in the nontradable sector. They suggest that following the 1995 crisis, firms not engaged in international trade were affected by a credit crunch. Willing but unable to access the domestic banking sector, these firms had no alternative but to finance themselves with their own resources. 
while the sharp credit contraction observed in the first half of 1995 was driven by a significant outflow of deposits from the banking system, bank's did recuperate their lending capacity towards mid-year. The credit contraction that ensued was partially driven by bank's having become more cautious in their lending practices-bank's opted to lend to the government, rather than to less-known or more-risky borrowers-and especially by a decline in credit demand-in turn the result of high private sector indebtedness and adverse expectations regarding economic activity.

Also, in reference to the experience of Argentina, Braun and Levy-Yeyati (2001) use a panel data estimation for the 1996-99 period to show that while credit contraction in small banks was mainly caused by a decline in deposits, that was not the case of the larger banks. The latter, in fact, were the main recipients of the deposits leaving the smaller banks. In the case of the larger banks, the paper provides evidence that the decline in their loans was mainly determined by their decision to move away from risky assets in the corporate sector, into safer assetsincluding cash and public sector debt.

In a recent paper, Berróspide and Dorich (2001) analyze the evolution of credit in Peru between 1997 and 2000. Using panel data estimation on monthly information for all 27 commercial banks, they estimate credit as a function of demand, supply and regulatory elements. Demand is proxied by GDP; supply is determined by loanable funds and proxies for sovereign as well as bank-specific risk; regulation is captured through the leverage coefficient. They report evidence in the sense that a period of credit slowdown associated with low GDP growth and a decline in loanable funds (late 1998 to late 1999) was followed by a credit slowdown that responded both to a tightening in regulation and to an increase in bank's risk perceptions. Interestingly, when controlling by size they find evidence that for large banks all credit slowdowns are supply-determined.

Using a very different approach, Carrasquilla et al. (2000) claim that the severe credit contraction observed in Colombia after 1998 was mainly due to bank's inability, rather than because of their unwillingness, to lend. They propose and estimate a model in which bank loans as a proportion of their liquid assets is positively associated with the level of deposits and negatively associated with bank's perceptions of risk in the corporate sector. They provide econometric evidence that, by far, the dominant factor in explaining the sharp contraction in bank loans was the decline in deposits which, in turn, they associate with an inadequate provision of liquidity on the part of the central bank.

In a recent paper, Gourinchas et al. (2001) take the discussion a step forward. They explicitly introduce credit booms as an explanatory argument for eventual financial crises. They report evidence that in Latin America lending booms do tend to make the economy more vulnerable to an eventual crises - that is, both in the financial sector and in the balance of payments. Interestingly, this type of regularity does not seem to hold for other regions in the world. 
Finally, Braun and Hausmann (2001) focus on credit crunches 5 throughout the world and find that in Latin America they tend to be closely associated with the deterioration in the region's access to foreign financing. Interestingly, this deterioration appears to be associated not only with the generalized curtailment of capital inflows to emerging markets, but also a sharp with decline in the terms of trade which made it that much more difficult for Latin American economies to provide the much needed collateral required to access foreign financing.

\section{Credit Stagnation in Latin America: A First LoOK}

In this section we describe the recent performance of bank credit in eight Latin American countries, including the seven largest-Argentina, Brazil, Chile, Colombia, Mexico, Peru, Venezuela, and Bolivia - highlighting the recent slowdown in many of these countries. First, we show the evolution of bank credit in its historical context, pointing out how the recent behavior compares to previous credit cycles over a period of about 30 years, and making an initial assessment of the relative severity of recent slowdowns. Secondly, we compare the slowdown with several international cases where the credit crunch phenomenon was hypothesized and studied. Finally, for each Latin American country in the study we focus on the last 20 years, using a simple balance sheet decomposition to detect where the major changes occurred in the behavior of banks from one period to the next.

\section{A. The Latin American Credit Slowdown in Historical and International Context}

Several differences and similarities arise in comparing the evolution of bank credit over the past 30 years in the Latin American countries in our sample. Using IFS data, in Figure 1 we plot the ratio of private sector bank credit to GDP for the 1960-2000 period. We show private sector credit both from Deposit Money Banks (DMB), as well as from the entire banking system, DMB plus Other Banking Institutions (OBI). ${ }^{6}$ While six out of eight countries-Brazil and Chile being the exception-exhibit a slowdown with some amount of decline in the ratio in recent years, ${ }^{7}$ the patterns for the entire period are not all alike. For Peru and Bolivia, the

\footnotetext{
${ }^{5}$ They define a credit crunch differently from other studies, as a severe deterioration in the "net flow of resources" from the banking system to the private sector. In turn, they define the net flow of resources as the percentage increase in nominal credit minus the nominal interest rate. Thus, a credit crunch defined in this manner can come about as a result of a decline in the growth rate of credit and/or an upward spike in the nominal interest rate.

${ }^{6}$ Although definitions vary across countries, DMB is meant to comprise institutions that raise a significant portion of their funds from the public in the form of demand deposits. OBIs, on the other hand, are banking institutions that raise little or no funds from demand deposits.

${ }^{7}$ Following Gourinchas, et al. (2000), we divide the end-year stock of private sector credit in year $t$ by the geometric average of GDP in years $t$ and $t+1$. Thus, we include forecasts of GDP for 2001, based on real GDP forecasts by the IMF and ECLA, and on the latest 12-month inflation figures available in 2001.
} 
slowdown appears to be a recent interruption in a long process of rapid credit growth after hyperinflation had virtually driven bank credit to zero. Brazil, Chile, Mexico and, especially, Argentina have experienced pronounced cycles since the 1960s. For Colombia there has been a more modest but steady upward trend in credit since 1960. Finally, Venezuela has experienced a sustained downward trend since the early $1980 \mathrm{~s}^{8}$

Given this decline in overall bank credit to the private sector, it is relevant to examine whether there has been a substitution towards financing by nonbank financial institutions. For most of the countries (Argentina, Bolivia, Brazil, Colombia, and Venezuela) this is clearly not the case, since the definition of OBIs is sufficiently broad to include such institutions as savings and loan or mortgage corporations, credit cooperatives, investment banks, and even financial funds ${ }^{9}$ (see Appendix Table A.1). However, in two of the countries, IFS provides an additional category, "Nonbank Financial Institutions" (NFI), which corresponds to leasing companies, stock brokerage houses, and distributor companies in Brazil, and to pension funds in Chile. As we show in Appendix Table A.2, substitution toward NFIs does not appear to have taken place in Brazil, where its relative importance actually fell during the credit slowdown of the late 1980s and has increased in recent years, precisely while bank credit is expanding. In Chile, on the other hand, the credit slowdown corresponded to a sharp rise of NFIs-pension funds-in the late 1980s. Finally, in the case of Mexico, we obtained Bank of Mexico information for Savings and Loan institutions (SLIs), investment societies, and stock brokerage houses, all of which we grouped into a nonbank category. Although SLIs constituted a very small share of credit-less $1 / 2$ a percentage point-security holdings by the other nonbank institutions have been expanding rapidly since late 1996, thus suggesting that corporate financing through the stock market has substituted to some degree for the slowdown in bank credit.

In order to assess the severity of the recent credit slowdown in historical context, we undertook a second exercise using 1960-2000 data, based on the Gourinchas, et al. (2000) study of credit booms throughout the world. The procedure consists of calculating the trend in the credit-GDP ratio and then defining a boom as a period in which the (relative or absolute) deviation from trend is above a certain threshold. As Gourinchas, et al. use several alternative threshold levels, we chose an intermediate level of 5 percent in absolute terms. We also defined a credit "bust" symmetrically as an observation in which the credit-GDP ratio lies more than 5 percentage

\footnotetext{
${ }^{8}$ Note that for several countries the distinction between DMB and all banks is quite important, especially until the end of the $1980 \mathrm{~s}$, but only in Colombia does the distinction matter throughout the entire sample. Although in Colombia there are significant gaps in the IFS data for the entire banking system-owing to gaps in the information on OBIs - the data do show a more pronounced credit cycle in the nineties for the banking system in comparison to DMBs alone, reflecting a boom-bust cycle affecting housing finance and particularly savings and loans institutions during this period.

${ }^{9}$ In the Bolivian case, however, there is preliminary evidence pointing towards an increasing role of nonbank financial institutions not included in IFS data, for instance, investment funds and the local capital market.
} 
points below trend. We used a Hodrick-Prescott filter ${ }^{10}$ to capture the trend, then calculated the absolute deviations from this trend. These are plotted in Figure 2, and the results are summarized in Table 2.

Among the countries experiencing a credit slowdown in recent years, only Bolivia, which seemed to show only a modest decline in credit growth in 1999-2000 from Figure 1, meets this criterion for a credit bust in recent years, with the credit-GDP ratio falling more than 6 percentage points below its trend in 2000. On the other hand, Venezuela and Chile, for whom credit peaked in the early 1980s and thus experienced the slowdown much earlier than in the other six countries, had at least one episode of credit bust in the late 1980 s or early 1990 s. For example, in Chile the credit-GDP ratio fell almost 7 percentage points below trend in 1991, and in Venezuela it fell 7 percentage points below trend in $1990 .^{11}$

Although the above analysis would suggest that the recent slowdowns have not been very severe, several issues suggest that we may be observing the initial stages of a more pronounced credit bust, or that by limiting the sample to banks we are also missing key information regarding the severity of the slowdown. First, although the Gourinchas, et al. methodology defines a boom episode as a period containing at least one observation outside the threshold, the entire episode is said to begin and end when a less stringent limit threshold is crossed. If the limit threshold is 2 percent, Peru may have entered a credit bust in 2000 . The same could be said for Mexico and, to a lesser degree, for Argentina and Colombia. Second, in 2001 credit has continued to decline in real terms in most of the countries in the sample, falling by between 0.4 percent (Peru) and 11 percent (Mexico), as Table 2 shows. Second, the experience of the earlier slowdowns, in Chile and Venezuela, demonstrated that they did become quite severe over time, qualifying as credit busts. So far the recent slowdowns have been relatively short, lasting about three years as opposed to thirteen years in Venezuela and seven years in Chile. Third, as in the earlier case of Venezuela, in Colombia the recent decline in the broader aggregate-all banks - is much more pronounced than for DMBs and might meet the criteria for a credit bust. A more complete data set would allow us to determine whether this is true.

How does the recent credit slowdown in Latin America compare to other well-known cases of credit stagnation around the world? In Figures 3 and 4 we plot credit-GDP ratios and deviations from trend for several countries where serious credit slowdowns have been studied: Finland, Indonesia, Japan, Korea, Thailand, and the U.S. In Figure 3 we have indicated the periods studied previously: the 1997-99 for Indonesia, Korea and Thailand in Ghosh \& Ghosh (1999), post-1992 for Finland in Pazarbasioglu (1997), post-1990 Japan in Woo (1999), and post-1989 for the U.S. in Bernanke \& Lown (1991) and Peek \& Rosengren (1995).

\footnotetext{
${ }^{10}$ Following Hodrick and Prescott's recommendations for annual data, we use a smoothing factor of 100 .

${ }^{11}$ It should be noted that in the excercises presented in the next section, in which we compare periods of credit expansion with periods of credit contraction, we do not use the HodrickPrescott filter for dating purposes.
} 
We also find significant variability in these experiences. Finland, Indonesia, ${ }^{12}$ and Thailand all register dramatic declines in credit-GDP in a relatively short period of time, Korea experienced a short-lived and small drop, while Japan and the U.S. exhibit much more modest although extended downturns in credit.

Figure 1. Credit-GDP Ratios in Latin America, 1960-2000
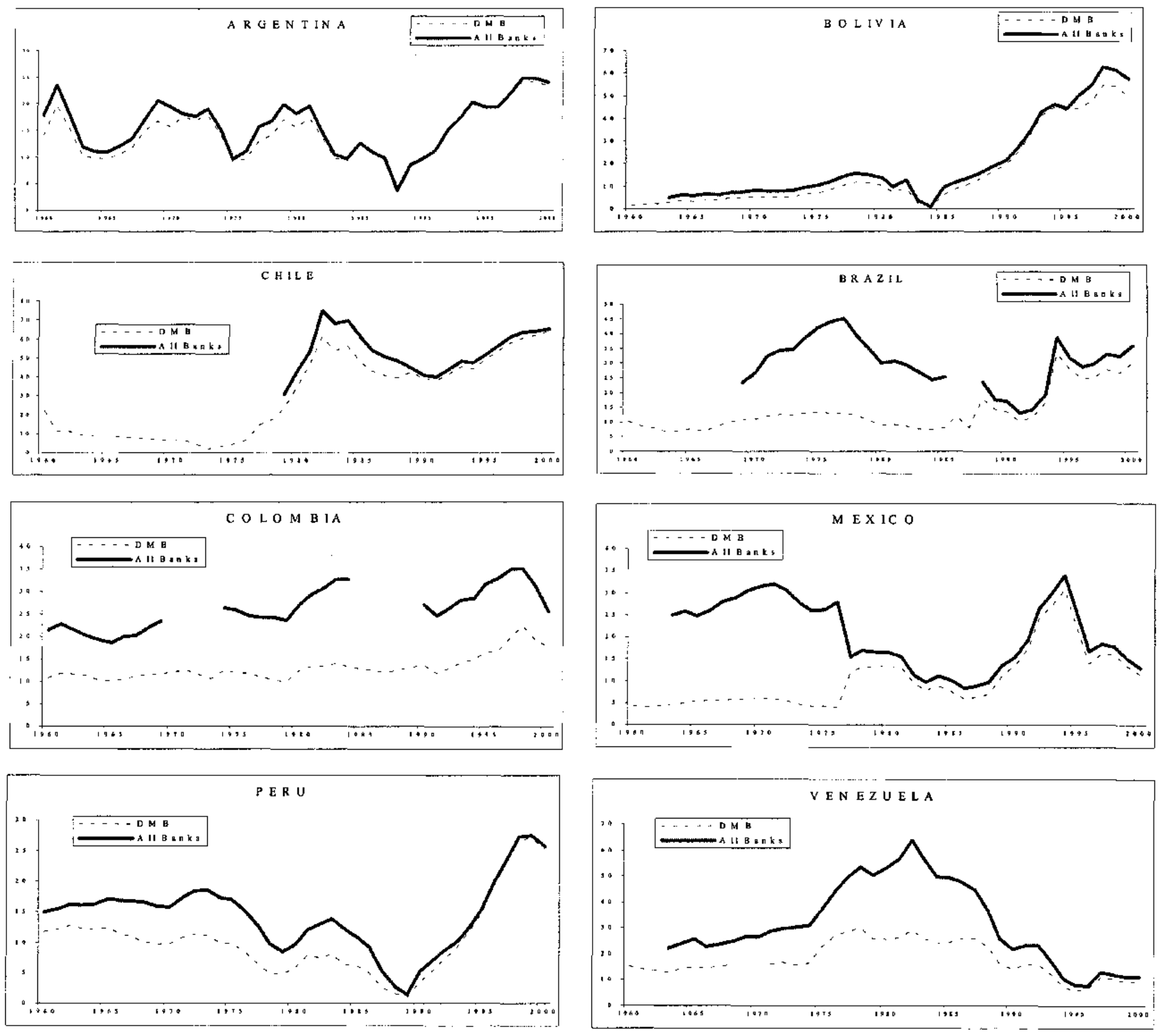

12 The sharpest decline observed in Indonesia, from 1998 to 1999, occurred outside the Ghosh \& Ghosh study period. 
Figure 2. Latin America-Absolute Deviations in the Credit-GDP Ratio with Respect to Trend
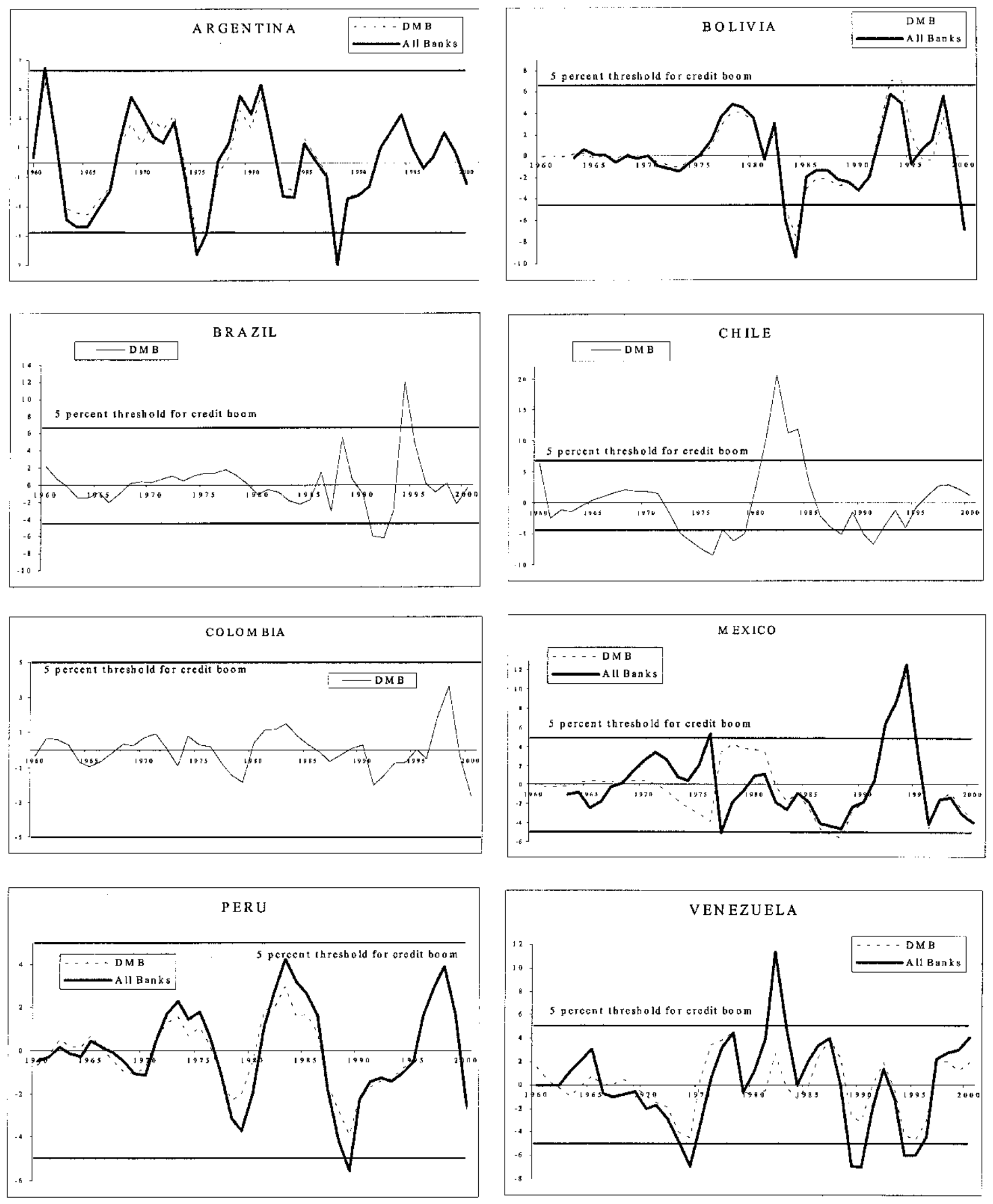
Figure 3. Credit-GDP Ratios 1960-2000-Selected Cases of Credit Slowdown
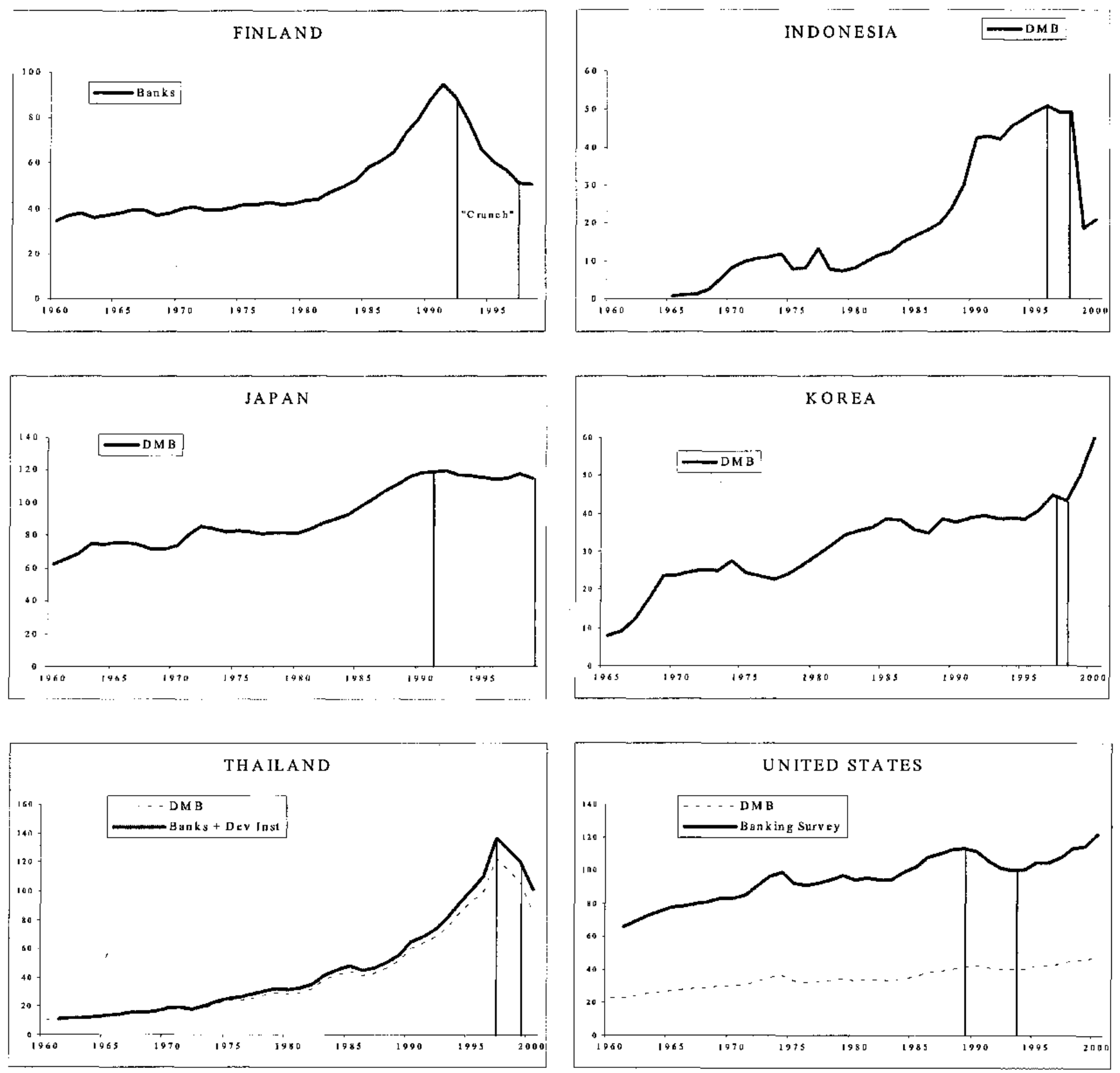
Figure 4. Absolute Deviations in the Credit-GDP Ratio with Respect to Trend Selected Cases of Credit Slowdown
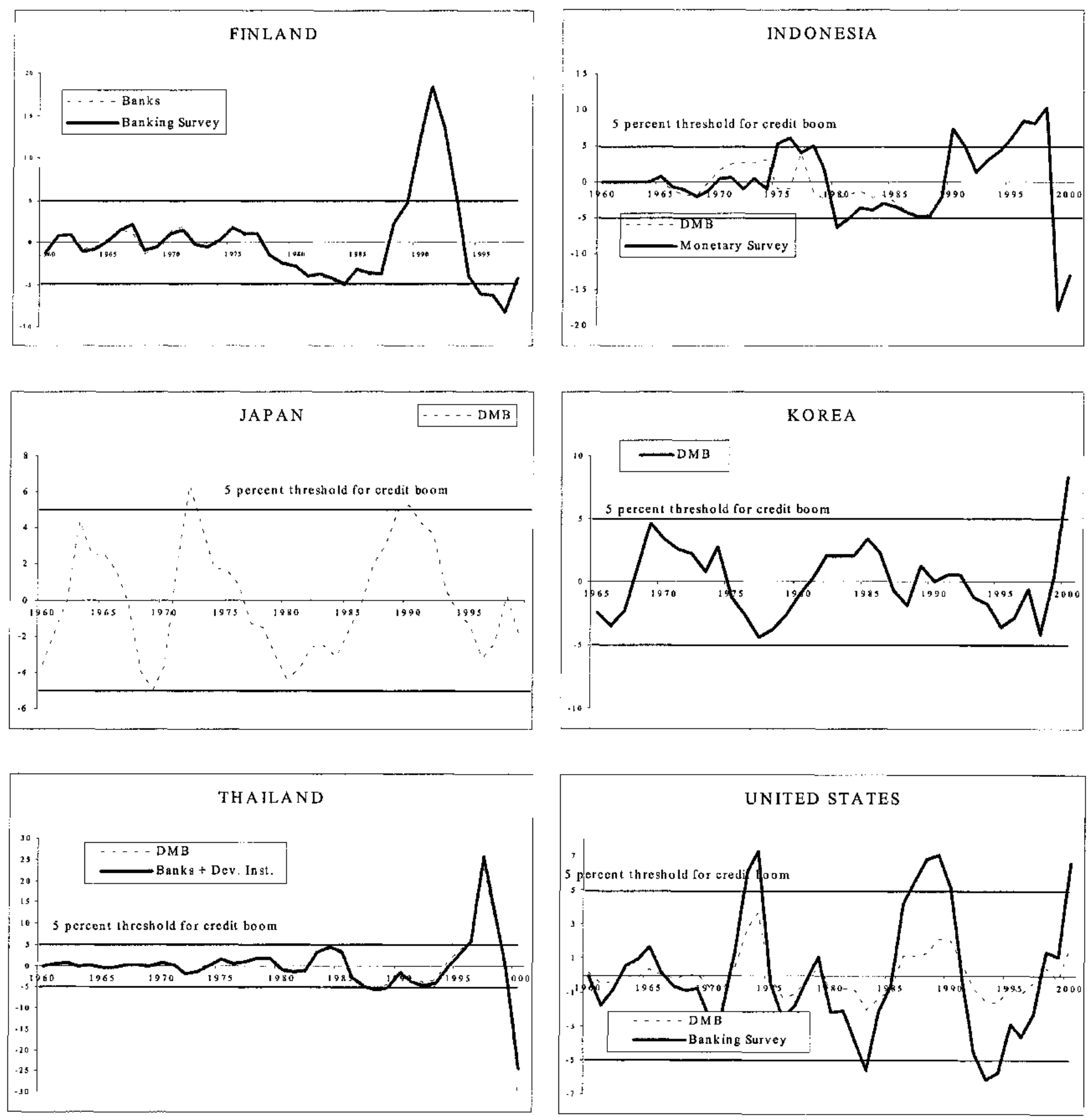
Table 2. Latin American Credit Slowdowns in Historical Context

\begin{tabular}{|c|c|c|c|c|c|c|c|c|}
\hline & Argentina & Bolivia & Brazil & Chile & Colombia & Mexico & Peru & Venezuela \\
\hline \multicolumn{9}{|l|}{ Deposit Money Banks } \\
\hline Average Credit/GDP 1960-2000 & 14.5 & 16.0 & 13.6 & 29.6 & 13.1 & 10.2 & 10.5 & 17.8 \\
\hline \multicolumn{9}{|l|}{ Most recent credit boom ${ }^{1}$} \\
\hline Relative & $1979-82$ & $1981-82$ & 1994 & $1981-84$ & none & $1992-95$ & $1981-86$ & none \\
\hline Absolute & 1961 & $1992-95$ & $1994-95$ & 1981.85 & none & $1992-95$ & none & none \\
\hline \multicolumn{9}{|l|}{ Deviation from trend ${ }^{2}$-recent years } \\
\hline 1997 & 0.40 & -0.44 & -0.90 & 2.61 & 1.89 & -1.54 & 2.95 & 2.00 \\
\hline 1998 & 1.94 & 3.68 & 0.16 & 2.72 & 3.65 & -0.94 & 3.75 & 1.97 \\
\hline 1999 & 0.47 & 0.29 & -2.29 & 2.00 & -0.40 & $-2,60$ & 1.49 & 1.26 \\
\hline 2000 & -1.52 & -6.75 & -0.36 & 1.01 & -2.62 & -3.59 & -2.74 & 1.92 \\
\hline \multicolumn{9}{|l|}{$\begin{array}{l}\text { Recent annual real growth rates } \\
\text { of credit }\end{array}$} \\
\hline 2000 & -3.1 & -6.6 & 11.9 & 6.6 & -4.1 & -13.9 & -4.9 & 10.6 \\
\hline $2001^{3}$ & -11.2 & -9.2 & -2.0 & 9.4 & 3.3 & -12.2 & -0.4 & 8.1 \\
\hline \multicolumn{9}{|l|}{ All Banks: Deposit Money Banks } \\
\hline \multicolumn{9}{|l|}{ \& Other Banking Institutions } \\
\hline Average Credit/GDP $1960-2000^{4}$ & 15.8 & 20.3 & 30.0 & 53.8 & 26.2 & 20.7 & 14.3 & 31.5 \\
\hline \multicolumn{9}{|l|}{ Most recent credit boom ${ }^{1}$} \\
\hline Relative & $1979-82$ & 1982 & n.a. & n.a. & n.a. & $1992-95$ & $1981-86$ & none \\
\hline Absolute & 1961 & 1998 & n.a. & n.a. & n.a. & $1992-95$ & none & $1982-83$ \\
\hline \multicolumn{9}{|l|}{ Deviation from trend ${ }^{2}$-recent years } \\
\hline 1997 & 0.35 & 1.48 & n.a. & n.a. & n.a. & -1.61 & 3.00 & 2.23 \\
\hline 1998 & 2.02 & 5.57 & n.a. & n.a. & n.a. & -1.40 & 3.92 & 2.80 \\
\hline 1999 & 0.64 & 0.57 & n.a. & n.a. & n.a. & -3.10 & 1.67 & 2.99 \\
\hline 2000 & -1.46 & -6.90 & n.a. & n.a. & n.a. & -3.96 & -2.50 & 4.08 \\
\hline \multicolumn{9}{|l|}{$\begin{array}{l}\text { Recent annual real growth rates } \\
\text { of credit }\end{array}$} \\
\hline 2000 & -3.1 & -5.0 & 10.1 & 6.0 & -15.2 & -12.2 & -4.9 & 5.3 \\
\hline $2001^{3}$ & -11.2 & -6.3 & -3.3 & 8.7 & -8.6 & -10.9 & -0.4 & -2.5 \\
\hline
\end{tabular}

Sources: International Financial Statistics, and authors' calculations.

${ }^{1}$ Defined as a period containing at least one year in which the credit-GDP ratio is at least 5 percentage points (absolute) or 25 percent (relative) above its trend value. See Gourinchas, et al. (2000) for details.

${ }^{2}$ Trend calculated using a Hodrick-Prescott filter on the original series, with smoothing factor $=100$.

${ }^{3}$ Twelve-month growth rate based on the latest monthly observation available: August 2001 (Brazil, Venezuela, Mexico, and Peru) and September 2001 (Chile, Argentina, Bolivia, and Colombia).

${ }^{4}$ Average taken over the longest period within $1960-2000$ for which data is available. 
We repeated the boom-bust analysis for this set of countries (Figure 4). Finland, Indonesia, Thailand, and the U.S. all clearly fit the criteria for a boom and bust cycle. Finland experienced a credit boom in the early 1990 s which brought credit-GDP to 18 percentage points above trend, followed immediately by a bust in which credit plummeted to 8 percentage points below trend by 1997. Indonesia and Thailand both reached the peak of their credit booms in the late 1990s, with credit-GDP well above the threshold, then went into a bust after the crisis, and

continue to lie below the threshold as of 2000 . Finally, for the entire banking system, ${ }^{13}$ the U.S. registered a credit bust in the early 1990s which was preceded by a boom from 1986 to 1989 . On the other hand, Japan experienced a credit boom in the early 1990s, but although credit has slowed appreciably, it has not met the criteria for an outright bust. According to our analysis, Korea experienced a boom in bank credit in 2000 , after a one-year decline that approached but did not breach the bust threshold.

The differences between the recent Latin American experience and that of other credit slowdowns is highlighted in Table 3, where we show the absolute declines in credit-GDP with respect to a peak level for each of the slowdown episodes. The largest total decline in creditGDP was 56 percentage points, experienced by Venezuela during 1983-95, followed closely by Finland's 44 percentage point contraction during 1992-97. On an annual basis, the largest declines were those of post-crisis Thailand and Indonesia, where over 10 percentage points were lost per year. In addition to Venezuela, other Latin American slowdowns have been quite substantial; credit-GDP fell by almost 30 percentage points in the case of all banks in Chile (1985-91) and about 19 percentage points for DMBs in Mexico, or over 3 percentage points per year, and over 4 percentage points per year for all banks in Colombia, all of which are comparable to or even greater than the credit crunch of the U.S. in the early 1990s. Again, since the recent Latin American slowdown cases are still relatively short, as opposed to a sixyear decline in Finland, for example, we may be observing the initial stage of a longer and more pronounced credit slowdown.

\section{B. The Latin American Credit Slowdown-Some Stylized Facts}

We now turn to a closer look at the evolution of credit and bank behavior in our eight countries over a shorter sample. In Tables 4 and 4 a we show average annual real growth rates of credit and deposits for different sub periods, as well as the ratios of credit to deposits and credit to total bank assets. For the six countries in which the credit slowdown is relatively recent (Argentina, Bolivia, Brazil, Colombia, Mexico, and Peru; Table 4), we divide the period into three portions: (1) the $1980 \mathrm{~s}$, which are characterized generally by relatively repressed financial markets and thereby low credit growth, (2) the credit expansion period of the early 1990 s, spurred in part by financial liberalization measures undertaken at the beginning of the decade, and (3) the recent slowdown. The expansion is defined as ending in the year when

${ }^{13}$ In the case of the U.S., the "banking system" category of the IFS encompasses all commercial banks, credit unions, savings institutions, and money market funds. 
Table 3. Latin American Credit Slowdowns in Comparison with Selected International Cases

\begin{tabular}{|c|c|c|c|c|}
\hline \multicolumn{5}{|c|}{ Credit to the Private Sector by the Banking System (except where otherwise indicated) } \\
\hline & $\begin{array}{l}\text { Slowdown } \\
\text { period }\end{array}$ & $\begin{array}{l}\text { Credit/GDP at } \\
\text { end of slowdown }\end{array}$ & $\begin{array}{l}\text { Difference vs. } \\
\text { most recent peak }\end{array}$ & $\begin{array}{l}\text { Average yearly } \\
\text { fall from peak }\end{array}$ \\
\hline \multicolumn{5}{|l|}{ Latin American countries } \\
\hline Argentina & $1999-2000$ & 24.1 & -0.7 & -0.3 \\
\hline Bolivia & $1999-2000$ & 57.6 & -5.2 & -2.6 \\
\hline Brazil & $1995-99$ & 32.4 & -6.4 & -1.3 \\
\hline Deposit Money Banks & & 26.7 & -6.7 & -1.3 \\
\hline Colombia & $1999-2000$ & 25.7 & -9.5 & -4.8 \\
\hline Deposit Money Banks & & 17.9 & -4.7 & -2.3 \\
\hline Chile & $1985-91$ & 40.0 & -29.6 & -4.2 \\
\hline Deposit Money Banks & & 38.0 & -18.0 & -2.6 \\
\hline Mexico & $1995-2000$ & 13.1 & -5.5 & -1.8 \\
\hline Deposit Money Banks & & 11.4 & -19.3 & -3.2 \\
\hline Peru & $1999-2000$ & 25.8 & -1.5 & -0.7 \\
\hline Venezuela & $1983-95$ & 8.0 & -56.0 & -4.3 \\
\hline Deposit Money Banks & & 5.9 & -23.4 & -1.8 \\
\hline \multicolumn{5}{|l|}{ Other cases of credit slowdown } \\
\hline Finland & 1992-97 & 51.2 & -44.3 & -7.4 \\
\hline Indonesia & $1997-99$ & 49.3 & -32.2 & -10.7 \\
\hline Japan (Deposit Money Banks) & $1993-99$ & 114.8 & -4.1 & -0.6 \\
\hline Korea (Deposit Money Banks) & $1997-98$ & 43.2 & -1.4 & -1.4 \\
\hline Thailand & $1998-2000$ & 101.1 & -35.6 & -11.9 \\
\hline United States & $1990-93$ & 100.1 & -13.0 & -3.2 \\
\hline
\end{tabular}

Sources: International Financial Statistics, Bank of Korea, and authors' calculations. 
Table 4. The Recent Credit Slowdown in Latin America: A Summary

\begin{tabular}{|c|c|c|c|c|c|c|}
\hline & Argentina & Bolivia & Brazil & Colombia & México & Perú \\
\hline \multicolumn{7}{|l|}{ Deposit Money Banks } \\
\hline 1. Preliberalization period & \multicolumn{6}{|c|}{$1980-1990$} \\
\hline a. Average real growth rates & & & & & & \\
\hline Credit to the private sector & -6.7 & 6.5 & 6.5 & 5.4 & 0.8 & -14.8 \\
\hline Deposits & -12.0 & 5.1 & 7.5 & 3.3 & -1.8 & -14.7 \\
\hline \multicolumn{7}{|l|}{ End-of-Period ratios } \\
\hline Loans/Deposits & 189.3 & 123.1 & 141.0 & 120.0 & 84.7 & 50.9 \\
\hline Loans/Assets & 53.0 & 79.1 & 48.4 & 65.4 & 65.6 & 27.7 \\
\hline Credit/GDP & 9.6 & 19.3 & 13.6 & 13.3 & 15.4 & 5.3 \\
\hline \multicolumn{7}{|l|}{ 2. Postliberalization period } \\
\hline a. Credit expansion period & \multicolumn{2}{|l|}{$1991-98$} & $1991-94$ & $1991-98$ & 1991-94 & $1991-98$ \\
\hline \multicolumn{7}{|l|}{ Average real growth rates } \\
\hline Credit to the private sector & 12.3 & 18.1 & 20.5 & 9.9 & 29.2 & 34.6 \\
\hline Deposits & 22.0 & 16.7 & 25.8 & 10.6 & 13.7 & 22.9 \\
\hline \multicolumn{7}{|l|}{ End-of-Period ratios } \\
\hline Loans/Deposits & 97.8 & 134.8 & 118.6 & 113.5 & 141.1 & 105.5 \\
\hline Loans/Assets & 61.9 & 82.9 & 63.3 & 71.8 & 87.2 & 69.8 \\
\hline Credit/GDP & 24.2 & 54.6 & 33.4 & 16.9 & 34.1 & 27.3 \\
\hline b. Credit slowdown period & \multicolumn{2}{|l|}{$1999-2000$} & \begin{tabular}{l|l|}
$1995-99$ \\
\end{tabular} & $1999-2000$ & \multicolumn{2}{|c|}{\begin{tabular}{|l|l|}
$1995-2000$ & $1999-2000$ \\
\end{tabular}} \\
\hline \multicolumn{7}{|l|}{ Average real growth rates } \\
\hline Credit to the private sector & -2.2 & -2.9 & 1.7 & -9.1 & -14.3 & -0.9 \\
\hline Deposits & 5.2 & -0.8 & -2.4 & 3.0 & -2.7 & 6.2 \\
\hline \multicolumn{7}{|l|}{ End-of-Period ratios } \\
\hline Loans/Deposits & 84.5 & 128.3 & 120.2 & 88.5 & 66.1 & 99.6 \\
\hline Loans/Assets & 57.1 & 79.9 & 58.3 & 61.2 & 32.2 & 68.1 \\
\hline Credit/GDP & 23.4 & 49.9 & 26.7 & 18.1 & 13.1 & 25.8 \\
\hline
\end{tabular}

Source: International Financial Statistics, and authors' calculations.

credit-GDP reached its peak of the $1990 \mathrm{~s}$, thus leading to the subsequent slowdown period. In Brazil and Mexico, credit reached its peak in 1995. In Argentina, Bolivia, Colombia, and Peru, credit peaked in 1998.

For the other two counties, Chile and Venezuela (Table 4a), the slowdown occurred earlier, and the more recent period is characterized by a recovery in credit growth. In Chile, financial markets were liberalized much sooner than in the rest of the region, while Venezuela observed a positive and significant terms of trade shock after 1973, and faced severe macroeconomic distress in the early 1990s. In both cases, there is significant credit expansion during the late 1970s and early 1980s, followed by sharp contractions-until 1991 in Chile and until 1995 in Venezuela. 
Table 4a. Earlier Credit Slowdowns in Latin America: A Summary

\begin{tabular}{|c|c|c|}
\hline & Chile & Venezeula \\
\hline \multicolumn{3}{|l|}{ Deposit Money Banks } \\
\hline 1. Credit expansion period & $1974-84$ & $1975-82$ \\
\hline \multicolumn{3}{|l|}{ Average real growth rates } \\
\hline Credit to the private sector & 39.4 & 8.6 \\
\hline Deposits & 15.1 & 7.6 \\
\hline \multicolumn{3}{|l|}{ End-of-Period ratios } \\
\hline Loans/Deposits & 256.1 & 93.8 \\
\hline Loans/Assets & 82.0 & 79.6 \\
\hline Credit/GDP & 56.1 & 29.3 \\
\hline 2. Credit slowdown period & $1985-91$ & $1983-95$ \\
\hline \multicolumn{3}{|l|}{ Average real growth rates } \\
\hline Credit to the private sector & 1.4 & -8.8 \\
\hline Deposits & 11.8 & -2.5 \\
\hline \multicolumn{3}{|l|}{ End-of-Period ratios } \\
\hline Loans/Deposits & 128.8 & 39.7 \\
\hline Loans/Assets & 86.4 & 37.7 \\
\hline Credit/GDP & 38.0 & 5.9 \\
\hline 3. Credit recovery period & $1992-2000$ & 1996-2000 \\
\hline \multicolumn{3}{|l|}{ Average real growth rates } \\
\hline Credit to the private sector & 11.0 & 6.3 \\
\hline Deposits & 9.7 & -4.8 \\
\hline \multicolumn{3}{|l|}{ End-of-Period ratios } \\
\hline Loans/Deposits & 142.6 & 69.2 \\
\hline Loans/Assets & 86.2 & 51.9 \\
\hline Credit/GDP & 64.0 & 9.5 \\
\hline
\end{tabular}

Sources: International Financial Statistics and authors' calculations. 
There are several consistent patterns across the first group of countries, those experiencing the recent slowdown. While in all cases real credit growth accelerated during the early $1990 \mathrm{~s}$, and subsequently slowed in the late $1990 \mathrm{~s}$, this behavior also occurred in bank deposits. The latter may have been the result of deregulation and financial reform programs undertaken early in the decade, which reduced taxes on financial intermediation, liberalized interest rates, and thereby encouraged savings through the banking system. Similarly, in the more recent period there may have been a disintermediation process following a period of financial turmoil, in which capital outflows took place and domestic bank deposits fell. Thus, it may be that the slowdown in credit was driven by a slowdown in deposits, and banks merely reacted passively in response to a squeeze on their loanable funds. However, our third observation is that although deposit growth was indeed a key factor, it does not appear to be the entire story. Indeed, except in the case of Brazil, in the other five countries the slowdown in credit is more pronounced than that in deposits. In fact, in some countries deposits continued to grow in real terms while real credit fell. Consequently, loans fell in relation to total assets, thus reflecting a change in the composition of bank balance sheets.

This behavior is not always symmetrical across the expansion and slowdown. During the expansion, three countries, Brazil, Colombia, and especially Argentina, registered deposit growth rates greater than credit growth rates. For Argentina and Colombia, the expansion phase was more pronounced for deposits while the slowdown phase was more pronounced for credit. For the remaining three countries, the entire cycle observed in the 1990 s was more pronounced on the credit side, thus the loan-deposit and loan-asset ratios increased during the expansion and fell during the slowdown.

In the cases of Chile and Venezuela, during the slowdown credit fell more rapidly than deposits, and during the recent recovery credit is growing faster than deposits. In fact, in the case of Venezucla, the credit recovery period is characterized by a slowdown in deposits. As a result, there is a sharp increase in loans in relation to deposits and total assets.

\section{A Decomposition of Credit Growth}

In this section we present a summarized balance sheet for commercial banks, and observe the major changes that took place in bank activitics in the sub periods described above. We use the balance sheet to decompose credit growth to the private sector into banks' sources of funds or in the alternative uses of funds. Based on IFS data, the major balance sheet items are:

Sources of funds (SF)

Deposits and other liabilities with private sector:

Net foreign liabilities:

Capital and other:

\section{IFS line items}

Demand, savings and time deposits; money the market funds, bonds, restricted deposits.

Foreign assets minus foreign liabilities and long-term foreign liabilities.

Capital and other items, net. 


\section{Alternative uses of funds (AUF)}

Net credit to the public sector:

Net credit to the central bank:
Claims on central and local government, public entities, public financial institutions, ${ }^{14}$ minus government deposits.

Reserves minus liabilities with the monetary authorities.

The distinction between "sources" and "uses" is not clear-cut. For example, accumulating foreign assets may be viewed as an alternative use, while contracting a long-term foreign debt should be considered a source of funds. However, the purpose was to keep a simple, sectoral classification that would yield a small number of groups that could be easily identified. We proceeded to decompose real credit growth to the private sector in the three periods by using the following balance sheet identity:

$$
\text { CREDIT }_{t}=S F_{t}-A U F_{t} \Rightarrow \frac{\Delta C R E D I T}{C R E D I T_{t}}=\frac{\Delta S F}{C R E D I T_{t}}-\frac{\Delta A U F}{C R E D I T_{t}}
$$

We present this decomposition in Tables 5 and $5 \mathrm{a}$, which show the contribution of each source or alternative use to bank credit growth in the three sub periods and for the two groups of countries mentioned in Table $4 .^{15}$

Again we observe how changes in deposit growth contributed to both the expansion and slowdowns of credit in the 1990s - and to the slowdown and subsequent expansion in Chile and Venezuela. We also see that other balance sheet items changed as well, thus credit did not move one-for-one with deposits. In general, credit and deposits move in the same direction, with the most notorious exceptions being Argentina and Mexico during the recent credit slowdown, in which deposits and other liabilities with the private sector actually increase, and Venezuela's recent credit recovery, in which deposits are falling.

In all countries but Bolivia and Chile, net credit to the public sector accelerated during the slowdown period, presumably competing with credit to the private sector and contributing to the slowdown. However, the opposite was not always true during the prior expansion. In that regard, maybe the most interesting case is the recent credit recovery in Venezuela, which has taken place in the context of a sharp contraction of net credit to the public sector-that is to say, by a rapid buildup of bank deposits by the decentralized agencies (that is, public enterprises).

${ }^{14}$ This item is only relevant for Mexico.

${ }^{15}$ In the case of Mexico, we analyzed the slowdown up to December 1996, as an accounting classification change in January 1997 made it difficult to compare various balance sheet items before and after this date. However, most of the decline is captured in the 1995-96 period, after which credit remained relatively stable for several years. In the case of Argentina, we analyzed the expansion after 1994, in order to isolate the measured variations from an accounting change at the end of 1993. 
Table 5. Decomposition of Credit Growth - Recent Cases of Slowdown

\section{Deposit Money Banks}

Average real growth rate of credit

Decomposition:

Sources of Funds

Deposits \& other liabilities with the private sector

Net foreign liabilities

Capital and other

Alternative uses of funds:

Net credit to the nonfinancial public sector

Net credit to the central bank

\section{Postliberalization period a. Credit expansion period}

Average real growth rate of credit

Decomposition:

Sources of Funds

Deposits \& other liabilities with the private sector Net foreign liabilities

Capital and other

Alternative uses of funds:

Net credit to the nonfinancial public sector

Net credit to the central bank

\section{b. Credit slowdown period}

Average real growth rate of credit

Decomposition:

Sources of Funds

Deposits \& other liabilities with the private sector

Net foreign liabilities

Capital and other

Alternative uses of funds:

Net credit to the nonfinancial public sector

Net credit to the central bank

Argentina Bolivia Brazil Colombia Mexico Peru

\begin{tabular}{rrrrrr}
\hline \multicolumn{6}{c|}{$1981-1990$} \\
\hline-6.7 & 6.5 & 6.5 & 5.4 & 0.8 & -14.8 \\
& & & & & \\
-9.2 & 4.5 & 11.7 & 4.5 & -1.9 & -29.0 \\
1.7 & -1.5 & -1.4 & 0.0 & -1.9 & -4.4 \\
-3.2 & 1.5 & 3.4 & 0.9 & 1.0 & 1.9 \\
& & & & & \\
1.4 & -0.1 & 1.8 & 0.0 & 2.8 & -5.7 \\
-5.4 & -1.9 & 5.4 & 0.0 & -6.3 & -11.0
\end{tabular}

\begin{tabular}{|l|l|l|l|l|l|}
\hline $1994-98$ & $1991-98$ & $1991-94$ & $1991-98$ & $1991-94$ & $1991-98$ \\
\hline
\end{tabular}

$\begin{array}{llllll}7.7 & 18.1 & 20.5 & 9.9 & 29.2 & 34.6\end{array}$

$\begin{array}{rrrrrr}11.5 & 12.9 & 11.9 & 9.8 & 12.7 & 29.9 \\ -0.4 & 2.5 & 1.1 & 0.5 & 3.1 & 6.5 \\ -0.4 & 2.2 & 3.5 & 0.3 & 3.8 & 3.3\end{array}$

$\begin{array}{rrrrrr}3.5 & 1.0 & 1.6 & 1.8 & -5.8 & -2.7 \\ -0.6 & -1.4 & -5.7 & -0.9 & -3.7 & 7.9\end{array}$

\begin{tabular}{|l|c|c|c|c|}
\hline $1999-2000$ & $1995-99$ & $1999-2000$ & $1995-1996$ & $1999-2000$ \\
\hline
\end{tabular}

$\begin{array}{llllll}-2.2 & -2.9 & 1.7 & -9.1 & -35.4 & -0.9\end{array}$

$\begin{array}{rrrrrr}5.5 & -0.4 & 5.5 & 0.2 & -5.6 & 1.8 \\ 1.3 & -6.2 & 1.8 & -1.9 & -1.8 & -4.5 \\ -4.7 & 3.5 & 6.2 & -4.5 & -2.7 & 3.3\end{array}$

$\begin{array}{llllll}4.1 & -0.4 & 7.8 & 2.9 & 7.4 & 1.0\end{array}$

$\begin{array}{llllll}0.2 & 0.2 & 4.0 & 0.0 & 17.8 & 0.5\end{array}$

Source: International Financial Statistics and authors' calculations. 
Table 5a. Decomposition of Credit Growth: Earlier Cases of Slowdown

Chile Venezuela

Deposit Money Banks

\section{Credit expansion period}

Average real growth rate of credit

Decomposition:

Sources of Funds

Deposits \& other liabilities with the private sector Net foreign liabilities

Capital and other

Alternative uses of funds:

Net credit to the nonfinancial public sector

Net credit to the central bank

\section{Credit slowdown period}

Avcrage real growth rate of credit

Decomposition:

Sources of Funds

Deposits \& other liabilities with the private sector

Net foreign liabilities

Capital and other

Alternative uses of funds:

Net credit to the nonfinancial public sector

Net credit to the central bank

\section{Credit recovery period}

Average real growth rate of credit

Decomposition:

Sources of Funds

Deposits \& other liabilitics with the private sector

Net foreign liabilities

Capital and other

Alternative uscs of funds:

Net credit to the nonfinancial public sector

Net credit to the central bank
1974-84

1975-82

39.4

8.6

17.4

23.2

8.4

$-21.1$

1.3

$-1.1$

$\begin{array}{rr}3.3 & 0.4 \\ -23.2 & -0.5\end{array}$

1985-91

1983-95

1.4

$-8.8$

7.1

$-6.3$

$-3.8$

5.0

$-1.4$

0.3

$-0.9$

2.9

5.3

1.0

1992-2000

1996-2000

11.0

6.3

10.1

$-9.1$

$-2.3$

0.3

4.2

3.4

$-0.2$

$-11.1$

1.2

$-0.6$

Source: International Financial Statistics and authors' calculations. 
In most cases, net foreign liabilities moved procyclically in both phases. For example, in Mexico and Peru they increased during the early expansion and then reversed sharply during the subsequent slowdown, thus reducing the amount of resources available for lending to the private sector. The notorious exception is Argentina, ${ }^{16}$ given its very particular exchange rate regime. The net foreign position had a dampening effect on credit growth; by expanding in the early 1990s and declining in the late 1990s, it offset the expansion as well as the slowdown. Upon closer inspection it becomes apparent that, for most countries, foreign liabilities rather than assets have tended to register the largest movements from one period to the next, thus generating the largest impact on credit growth. However, two major exceptions are Chile and Mexico, which registered substantial increases in foreign assets throughout most of the 1990 s. $^{17}$

In order to focus on the factors underlying credit growth in the 1990s, we highlight the changes from period to period in Tables 6 and $6 \mathrm{a}$. For the six recent slowdown cases, we show the changes in average growth rates, first from the 1980s to the expansion period, and then from the expansion to the slowdown period. For the two early slowdown cases, we focus on the differences between the slowdown and expansion period first, then on the differences between the recovery and the slowdown. Taking Argentina, for example, we have real credit growth accelerating from a negative rate of 6.7 percent during the $1980 \mathrm{~s}$ to a positive rate of 7.7 percent in the early $1990 \mathrm{~s}$, thus, a turnaround of 14.4 percentage points. As the decomposition shows, this is matched to a large extent by a turnaround in deposit growth, the major contributing factor, amounting to 20.7 percentage points, and offset by several factors, including an acceleration in banks' net position with respect to the central bank of 4.8 percentage points. In turn, during the slowdown credit decelerated by 10 percentage points, with a 10.3 point decline in deposit and capital growth.

We then summarize the major changes in banks' balance sheets in Tables 7 and $7 \mathrm{a}$, where we also indicate the four balance sheet factors that had the greatest impact on credit growth in each case, and distinguish whether their behavior contributed to or offset the changes in credit from one period to another. A number of characteristics of the credit cycle in Latin America become apparent. First, the single most important factor contributing to the changes in credit growth was deposit growth. For five of the eight countries it had the largest impact during the expansion, and for (another set of) five it had the largest impact during the slowdown. There is not one case in which deposits were not the dominant factor in at least one of the two phases, and in four countries-Argentina, Bolivia, Colombia, and Peru - they were the dominant factor in both phases.

${ }^{16}$ And Chile during the recent credit recovery period.

${ }^{17}$ In Chile, the share of foreign assets in total bank assets tripled between 1991 and 2000 (growing from 3 to 9 percent), and in Mexico it grew by a factor of 10 between 1994 and 2000 (from 0.4 to 4 percent). 
Table 6. Components of Credit Growth: Differences with Respect to Previous Periods

\begin{tabular}{|c|c|c|c|c|c|c|}
\hline & Argentina & Bolivia & Brazil & Colombia & Mexico & Peru \\
\hline \multicolumn{7}{|l|}{ Deposit Money Banks } \\
\hline Credit expansion period vs. preliberalization & $1994-98$ & $1991-98$ & 1991-94 & $1991-98$ & $1991-94$ & $1991-98$ \\
\hline $\begin{array}{l}\text { Average real growth rate of credit } \\
\text { Decomposition: }\end{array}$ & 14.4 & 11.6 & 14.0 & 4.5 & 28.4 & 49.4 \\
\hline \multicolumn{7}{|l|}{ Sources of Funds } \\
\hline Deposits \& other liabilities with the private sector & 20.7 & 8.5 & 0.2 & 5.4 & 14.6 & 58.9 \\
\hline Net foreign liabilities & -2.1 & 4.0 & 2.5 & 0.5 & 5.0 & 10.9 \\
\hline Capital and other & 2.8 & 0.7 & 0.1 & -0.6 & 2.8 & 1.4 \\
\hline \multicolumn{7}{|l|}{ Alternative uses of funds: } \\
\hline Net credit to the nonfinancial public sector & 2.1 & 1.1 & -0.2 & 1.8 & -8.6 & 3.0 \\
\hline Net credit to the central bank & 4.8 & 0.5 & -11.0 & -0.9 & 2.6 & 18.9 \\
\hline Credit slowdown vs. expansion period & \multicolumn{2}{|c|}{$1999-2000$} & $1995-99$ & $1999-2000$ & \multicolumn{2}{|c|}{\begin{tabular}{l|l|l}
$1995-96$ & $1999-2000$ \\
\end{tabular}} \\
\hline Average real growth rate of credit & -10.0 & -21.0 & -18.8 & -18.9 & -64.6 & -35.5 \\
\hline \multicolumn{7}{|l|}{ Decomposition: } \\
\hline \multicolumn{7}{|l|}{ Sources of Funds } \\
\hline Deposits \& other liabilities with the private sector & -6.0 & -13.3 & -6.4 & -9.6 & -18.4 & -28.2 \\
\hline Net foreign liabilities & 1.8 & -8.7 & 0.7 & -2.4 & -4.9 & -11.0 \\
\hline Capital and other & -4.3 & 1.3 & 2.7 & -4.9 & -6.6 & 0.0 \\
\hline \multicolumn{7}{|l|}{ Alternative uses of funds: } \\
\hline Net credit to the nonfinancial public sector & 0.7 & -1.4 & 6.2 & 1.1 & 13.3 & 3.7 \\
\hline Net credit to the central bank & 0.8 & 1.6 & 9.6 & 0.9 & 21.5 & -7.4 \\
\hline
\end{tabular}

Source: International Financial Statistics and authors' calculations. 
Table 6a. Components of Credit Growth: Differences with Respect to Previous Period

\begin{tabular}{|c|c|c|}
\hline & Chile & Venezuela \\
\hline \multicolumn{3}{|l|}{ Deposit Money Banks } \\
\hline Credit slowdown vs. expansion period & $1985-91$ & $1983-95$ \\
\hline Average real growth rate of credit & -38.1 & -17.4 \\
\hline \multicolumn{3}{|l|}{ Decomposition: } \\
\hline \multicolumn{3}{|l|}{ Sources of Funds } \\
\hline Deposits \& other liabilities with the private sector & -10.3 & -12.2 \\
\hline Net foreign liabilities & -29.5 & -2.7 \\
\hline Capital and other & 26.0 & 1.5 \\
\hline \multicolumn{3}{|l|}{ Alternative uses of funds: } \\
\hline Net credit to the nonfinancial public sector & -4.2 & 2.5 \\
\hline Net credit to the central bank & 28.5 & 1.5 \\
\hline Credit recovery ys. slowdown period & $1992-2000$ & $1996-2000$ \\
\hline Average real growth rate of credit & 9.6 & 15.1 \\
\hline \multicolumn{3}{|l|}{ Decomposition: } \\
\hline \multicolumn{3}{|l|}{ Sources of Funds } \\
\hline Deposits \& other liabilities with the private sector & 3.0 & -5.3 \\
\hline Net foreign liabilities & 4.0 & 1.7 \\
\hline Capital and other & -0.8 & 3.1 \\
\hline \multicolumn{3}{|l|}{ Altcrnative uses of funds: } \\
\hline Net credit to the nonfinancial public sector & 0.7 & -14.0 \\
\hline Net credit to the central bank & -4.1 & -1.6 \\
\hline
\end{tabular}

Source: Table 4. 
Table 7. Major Factors Contributing to Changes in Credit Growth

\begin{tabular}{|c|c|c|c|c|c|c|}
\hline & Argentina & Bolivia & Brazil & Colombia & Mexico & Peru \\
\hline \multicolumn{7}{|l|}{ Credit expansion period vs. preliberalization } \\
\hline Change in annual real credit growth & 14.4 & 11.6 & 14.0 & 4.5 & 28.4 & 49.4 \\
\hline \multicolumn{7}{|l|}{ Major factors accelerating credit growth } \\
\hline First major factor & Deposits & Deposits & Central Bank & Deposits & Deposits & Deposits \\
\hline Contribution & 20.7 & 8.5 & 11.0 & 5.4 & 14.6 & 58.9 \\
\hline Second major factor & Capital/Other & Foreign & Foreign & Central Bank & NFPS & Foreign \\
\hline Contribution & 2.8 & 4.0 & 2.5 & 0.9 & 8.6 & 10.9 \\
\hline \multicolumn{7}{|l|}{ Major offsetting factors } \\
\hline First major factor & Central Bank & NFPS & None & NFPS & \multicolumn{2}{|c|}{ Central Bank Central Bank } \\
\hline Contribution & -4.8 & -1.1 & & -1.8 & -2.6 & -18.9 \\
\hline Second major factor & NFPS & Central Bank & None & Capital/Other & None & None \\
\hline Contribution & -2.1 & -0.5 & & -0.6 & & \\
\hline Relative contribution of deposits (percent) & 143.3 & 73.2 & 1.6 & 119.6 & $5 \mathrm{I} .4$ & 119.4 \\
\hline Combined effect of major factors & 16.5 & 10.9 & 13.5 & 4.0 & 20.5 & 51.0 \\
\hline Percent of total change in credit growth & 114.6 & 94.2 & 96.6 & 87.8 & 72.3 & 103.3 \\
\hline \multicolumn{7}{|l|}{ Credit slowdown vs. expansion period } \\
\hline Change in annual real credit growth & -10.0 & -21.0 & -18.8 & -18.9 & -64.6 & -35.5 \\
\hline \multicolumn{7}{|l|}{ Major factors slowing credit growth } \\
\hline First major factor & Deposits & Deposits & Central Bank & Deposits & Central Bank & Deposits \\
\hline Contribution & -6.0 & -13.3 & -9.6 & -9.6 & -21.5 & -28.2 \\
\hline Second major factor & Capital/Other & Foreign & Deposits & Capital/Other & Deposits & Foreign \\
\hline Contribution & -4.3 & -8.7 & -6.4 & -4.9 & $-I 8.4$ & -11.0 \\
\hline \multicolumn{7}{|l|}{ Major offsetting factors } \\
\hline First major factor & Foreign & NFPS & Capital & None & \multicolumn{2}{|c|}{ None Central Bank } \\
\hline Contribution & 1.8 & 1.4 & 2.7 & & & 7.4 \\
\hline Second major factor & Central Bank & Capital/Other & Foreign & None & None & None \\
\hline Contribution & 0.8 & 1.3 & 0.7 & & & \\
\hline Relative contribution of deposits (percent) & 60.2 & 63.4 & 34.2 & 50.8 & 33.2 & 79.3 \\
\hline Combined effect of major factors & -7.7 & -19.4 & -12.6 & -14.5 & -39.8 & -31.8 \\
\hline Percent of total change in credit growth & 77.3 & 92.2 & 67.1 & 76.5 & 61.7 & 89.5 \\
\hline
\end{tabular}

Source: Table 4. 
Table 7a. Major Factors Contributing to Changes in Credit Growth

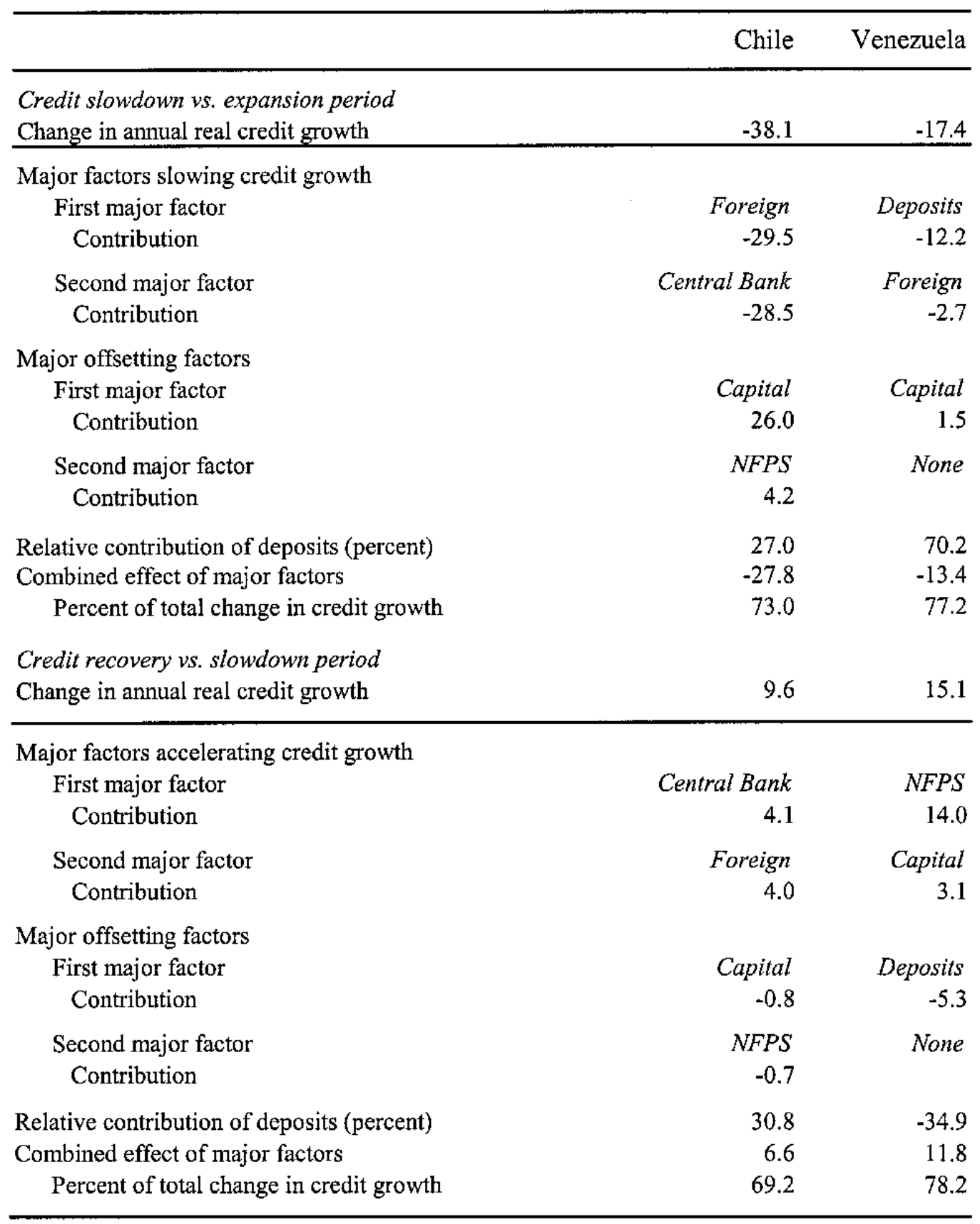

Source: Table 4. 
Second, the co-movement of deposit and credit growth dropped somewhat during the slowdown; taking a simple average of the relative contribution of deposits to credit growth changes across the eight countries, we find that deposits accounted for 63 percent of the acceleration in credit growth during the expansion, and for 53 percent of the recent deceleration. Excluding Venezuela, where the recent credit upswing came together with a decline in deposits, the co-movement drops from 77 to 50 percent, when comparing expansions and contractions.

Third, the net position with the central bank generally played an important role, albeit for different reasons. In three countries net central bank credit—a proxy for monetary policy-has been highly procyclical. In the case of Brazil, it was the dominant accelerating factor during the expansion and the dominant decelerating factor during the contraction. In Chile it was the dominant accelerating element during the expansion period and a major decelerating factor during the credit contraction. In Mexico net central bank credit was the dominant factor decelerating credit during the recent slowdown. On the other hand, in Argentina and Peru, and to a lesser extent in Colombia and Bolivia, net credit to the central bank played an off-setting role, contracting during the expansionary period and expanding during the contraction. It is worth highlighting that only in the case of Peru it holds that the central bank was the major off-setting factor in both phases, as reserve requirements were kept high during the expansion and were relaxed during the decline.

Fourth, except in the cases of Colombia and Mexico, net foreign liabilities (NFL) of banks played an important role in credit growth. They were a major contributing factor during both phases in Bolivia, Peru, ${ }^{18}$ and Chile and played an accelerating role in Venezuela's contraction. On the other hand, They were a major offsetting element in the recent credit contractions of Argentina and Brazil.

Fifth, a fiscal factor (labeled NFPS in Table 7) played a major role in accelerating Mexico's credit in the early 1990s and in Venezuela's recent credit recovery. In Bolivia and Chile, and to a lesser extent in Argentina and Colombia, credit to the public sector on occasions acted as a major offsetting factor-for example, accelerating during the expansion period. Regarding the slowdown, net credit to the NFPS was a significant contributing factor-albeit not always a major one-for all countries except Bolivia and Chile. This may reflect a fiscal expansion which squeezed out private sector credit, and/or a reduction in risk-taking by banks, who may

${ }^{18}$ It has been argued that, by using end-year period figures in the case of Peru, we are overstating the importance of deposits and understating that of the decline in foreign credit lines $(N F L)$, as the latter began in mid-1998. However, we repeated the balance decomposition exercise using mid-year (June) figures, and found that although the effect of NFL does increase, from 11 percent of credit growth (Table 6) to over 12 percent, deposits still remain the dominant factor, contributing over 20 percent of credit growth. Although NFL reversesbecomes a net outflow-during the slowdown, while deposits continue to increase, the crucial point is that the deceleration of deposits, (from 31 to 3 percent relative to credit, when using mid-year figures) still has the strongest impact on credit growth. 
have decided to increase their holdings of relatively safe government securities rather than increase loans, as argued by Catao (1997) in the Argentinean case.

Finally, the private sector credit slowdown appears to be more complex than the expansion, in the sense that it involves changes in a larger number of balance sheet items, as Tables 6 and 7 show. Except in the case of Chile, in all countries we find that the aggregate relative contribution of a small number of factors, two contributing, two offsetting, falls, and sometimes considerably, from the expansion to the slowdown. For example, in Argentina the major factors accounted for 115 percent of the credit expansion, but for only 77 percent of the slowdown.

\section{ECONOMETRIC ANALysis}

\section{A. Methodological Issues}

Following recent studies of credit stagnation in selected East Asian and Latin American countries (Ghosh \& Ghosh, 1999; Pazarbasioglu,1997; Kim, 1999; and Barajas, López, and Oliveros, 2001) we estimated aggregate demand and supply functions for credit in three of the countries analyzed: Colombia, Mexico, and Peru. The econometric approach used is based on pioneering work by Laffont and García (1977) and Sealey (1979), and consists of estimating the system of supply and demand functions under the assumption that, at a given point in time, the credit market may either exhibit equilibrium, or temporary excess demand or supply owing to imperfect flexibility in the interest rate in the short run. Thus, in addition to capturing the main determinants of credit growth, the approach also allows one to assess whether a situation of excess demand, or credit crunch, occurred during an episode of declining credit growth.

Actual credit observed at time $t, C_{t}$, is defined as lying either on the supply curve (excess demand), on the demand curve (excess supply), or on both (equilibrium):

$$
C_{t}=\min \left(C^{s}, C^{d}\right)
$$

where $C_{t}^{s}$ and $C_{t}{ }_{t}$ are the supply and demand functions, respectively, defined as a function of the vectors of explanatory variables $X_{l l}$ and $X_{2 l}$, and error terms:

$$
\begin{aligned}
& C_{t}^{s}=X_{1 t} \beta^{s}+u_{1 t} \\
& C_{t}^{d}=X_{2 t} \beta^{d}+u_{2 t}
\end{aligned}
$$

Without adequate information on the price adjustment process, and assuming that the errors $u_{I}$ and $u_{l}$ are normally distributed, a likelihood function may be determined for the above model. Defining $\lambda_{t}$ as the probability that a given observation $t$ lies on the supply function (that is, demand is greater than supply), and given that $\mathrm{g}(\cdot)$ is the joint density function for supply and demand derived from the joint density function for $u_{1}$ and $u_{2}$, then the density function for $C_{t}$ under the assumption of excess demand is:

$$
h\left(C_{t} \mid C_{t}=C_{t}^{s}\right)=\int_{\mathcal{L}_{t}}^{\infty} g\left(C_{t}^{d}, C_{t}\right) \partial C_{t}^{d} / \lambda_{t}
$$


Similarly, the density function under the assumption of excess supply is:

$$
h\left(C_{t} \mid C_{t}=C_{t}^{d}\right)=\int_{\alpha_{t}}^{\infty} g\left(C_{t}, C_{t}^{s}\right) \partial C_{t}^{s} /\left(1-\lambda_{t}\right)
$$

The unconditional density function is then equal to:

$$
\begin{aligned}
& h\left(C_{t}\right)=\lambda_{t} h\left(C_{t} \mid C_{t}=C_{t}^{s}\right)+\left(1-\lambda_{t}\right) h\left(C_{t} \mid C_{t}=C_{t}^{d}\right) \\
& =\int_{C_{t}}^{\infty} g\left(C_{t}^{d}, C_{t}\right) \partial C_{t}^{d}+\int_{C_{t}}^{\infty} g\left(C_{t}, C_{t}^{s}\right) \partial C_{t}^{s}
\end{aligned}
$$

The likelihood function is $L=\prod_{t} h\left(Q_{t}\right)$, and the corresponding log likelihood to be maximized subject to the parameter values is:

$$
\sum_{i=0}^{T} \log h\left(Q_{t}\right)
$$

Maximization of equation (6) permits the estimation of both equations as well as the estimation of the probability of observed credit lying on either of the curves, $\lambda .{ }^{19}$ As in previous studies, we used OLS estimates of the supply and demand functions to provide initial values for the coefficients and standard errors for each equation. Although Maddala (1983) warns that the likelihood function is unbounded for certain parameter values, we found the OLS estimates to perform well as starting values, and convergence tended to occur relatively quickly.

In considering the specification of supply and demand functions, several issues emerge. First, identification of the model requires that one or more variables included in one function be excluded from the other. The past studies using this approach have used one key variable, lending capacity, $(L C)$, to distinguish the supply from the demand function. Lending capacity, defined as the availability of loanable funds to banks, would affect banks' ability to lend but would not have impact on firm or household demand for credit. We also followed this approach, including as $L C$ a subset of loanable funds over which banks have little discretionary power to influence in the short run, therefore constituting an exogenous determinant of bank credit.

A second specification issue involves variables reflecting the macroeconomic and business environment, since one expects credit demand to be positively related to these present and future expected conditions, and credit supply to respond to these variables to the extent that they would affect the riskiness of loans. As in previous studies, we included manufacturing production indices $(M A N U F)$, quarterly (or, in some cases, monthly) GDP measures $(y)$, the

${ }^{19}$ Details of this maximum likelihood method are discussed in Maddala (1983) and in Gourieroux (2000). 
output gap $(G A P),{ }^{20}$ the expected inflation rate $(I N F E)^{21}$ as a measure of macroeconomic stability, and the stock market index (STKMKT). It should be noted that the latter variable, as discussed in Ghosh \& Ghosh (1999), may also reflect the availability and attractiveness of alternatives to bank credit - equity finance in particular-from the demand side. Thus, the stock market index will have a positive coefficient if the macro conditions effect dominates, or a negative coefficient if the substitution effect dominates.

Third, also as in previous studies, we included interest rates on deposits $(i d)$ and on government securities $(i g)$ as proxies for the opportunity cost of bank credit either from the demand or supply side.

Fourth, in contrast to previous studies, for Peru and Mexico we also included the countryspecific JP Morgan EMBI price, ${ }^{22}$ which we expected to have dual effects similar to those of the stock market index. A positive impact on credit demand would arise if the dominant effect was an improvement in macroeconomic conditions, while a negative effect would arise when the EMBI signals an increase in foreign investors' willingness to lend to domestic residents, thus drawing customers away from bank credit.

Finally, also in contrast to previous studies, we included two additional variables specific to the supply function, the ratio of nonperforming loans total loans $(N P L)$, and the ratio of loan-loss provisions to nonperforming loans (PROV) ${ }^{23}$ The former reflects past credit risk and may signal financial difficulties in the banking system, while the latter reflects the severity of regulations on risk-taking in lending activities. If banks are reasonably well behaved, they would tend to lower their credit supply in response to mounting credit risk and/or increasing loan-loss provisions being imposed upon them. ${ }^{24}$

${ }^{20}$ This variable is used only in the Colombian case, and is obtained as a linear monthly interpolation of the quarterly output gap series constructed by Misas \& López (2001).

${ }^{21}$ We defined $I N F E_{t}$ as a three-month moving average of the twelve-month inflation rate, centered at month $t$.

${ }^{22}$ For Colombia, the EMBI price was introduced too recently to be used in the estimations.

${ }^{23}$ Also, in the case of Colombia and Peru, we included in the supply function the lagged regulatory capital ratio (capital to risk weighted assets), however, this variable generally did not perform well in the initial OLS estimations and thus tended to lead to convergence problems in the ML estimation.

${ }^{24}$ We use provisions as a leading indicator of loans because in our setup provisions are a proxy for the severity of regulations regarding risk taking. Other things equal, stiffer regulations today suggest lower credit supply tomorrow. This does not contradict the fact that each specific provisioning act is, in practice, preceded by a credit decision (as discussed in Blaschke, et al., 2001). In the latter case, the lag between provisioning and credit is, of course, almost impossible to disentangle from aggregate data. 
Given the econometric approach and the specification described above, in the next sections we describe the specific estimation results for each of the three countries, as shown in Tables 8-10. In all cases, the dependent variable was the natural log of real credit to the private sector, $L R C R E D$, with subtle differences in definition from country to country, as we explain below. In each table we report the estimated parameters with their respective t-statistics, the value of the log-likelihood function, and the $\mathrm{R}^{2}$ for the initial OLS estimations of the supply and demand functions. Finally, since the dependent variable was found to exhibit a unit root in all three countries, ${ }^{25}$ we conducted tests to determine whether real credit and its predicted value in each case formed a cointegrating vector. ${ }^{26}$ In the bottom portion of Tables 8-10, for each regression we show the trace statistic, ${ }^{27}$ which rejects the null hypothesis of no cointegration in virtually all cases and at least at the 5 percent level. Thus, even though real credit has a unit root, it is appropriate to estimate the model in levels.

\section{B. Colombia}

We used both monthly and quarterly data. Monthly data was available from September 1992 to March 2001, while quarterly information was available from the last quarter of 1991 to the second quarter of 2001. Quarterly estimations allowed us to use the quarterly GDP directly. We do not report OLS estimations, which in most instances provided coefficients that were statistically significant, and with the expected sign. In order to partially deal with endogeneity problems, we use lagged values of provisions, nonperforming loans, manufacturing output, stock market indices, and real lending capacity. Most of the variables are also taken in natural logs, so that coefficients can be interpreted as elasticities.

In Table 8 we report the results of the disequilibrium ML estimation, both for the monthly and the quarterly data sets. In the first three columns we present the results for DMBs, and in the last three columns we present those for the entire financial system, adjusted by loan write offs to offset accounting changes that may not reflect the true flow of bank credit to the private sector. $^{28}$

${ }^{25}$ The ADF test overwhelmingly fails to reject the null hypothesis of a unit root for all definitions of real credit used in the estimations, and for a wide variety of specifications and lags. These test results are available upon request.

${ }^{26}$ We also tested whether real credit was cointegrated with the dernand-side determinants, on the one hand, and the supply side determinants, on the other. The results also supported the existence of a cointegrating vector.

${ }^{27}$ The maximum eigenvalue statistic yielded the same results.

${ }^{28}$ Peek and Rosengren (1995) undertake a similar adjustment in the case of the U.S. in the early 1990 s to differentiate changes in the stock of credit from changes in flows of credit to the private sector. We obtained the unadjusted series from IFS data, and the adjusted series for the financial system from the Colombian Banking Superintendency. 
Table 8. Colombia. Credit Demand and Supply Estimations (Maximum likelihood disequilibrium estimation)

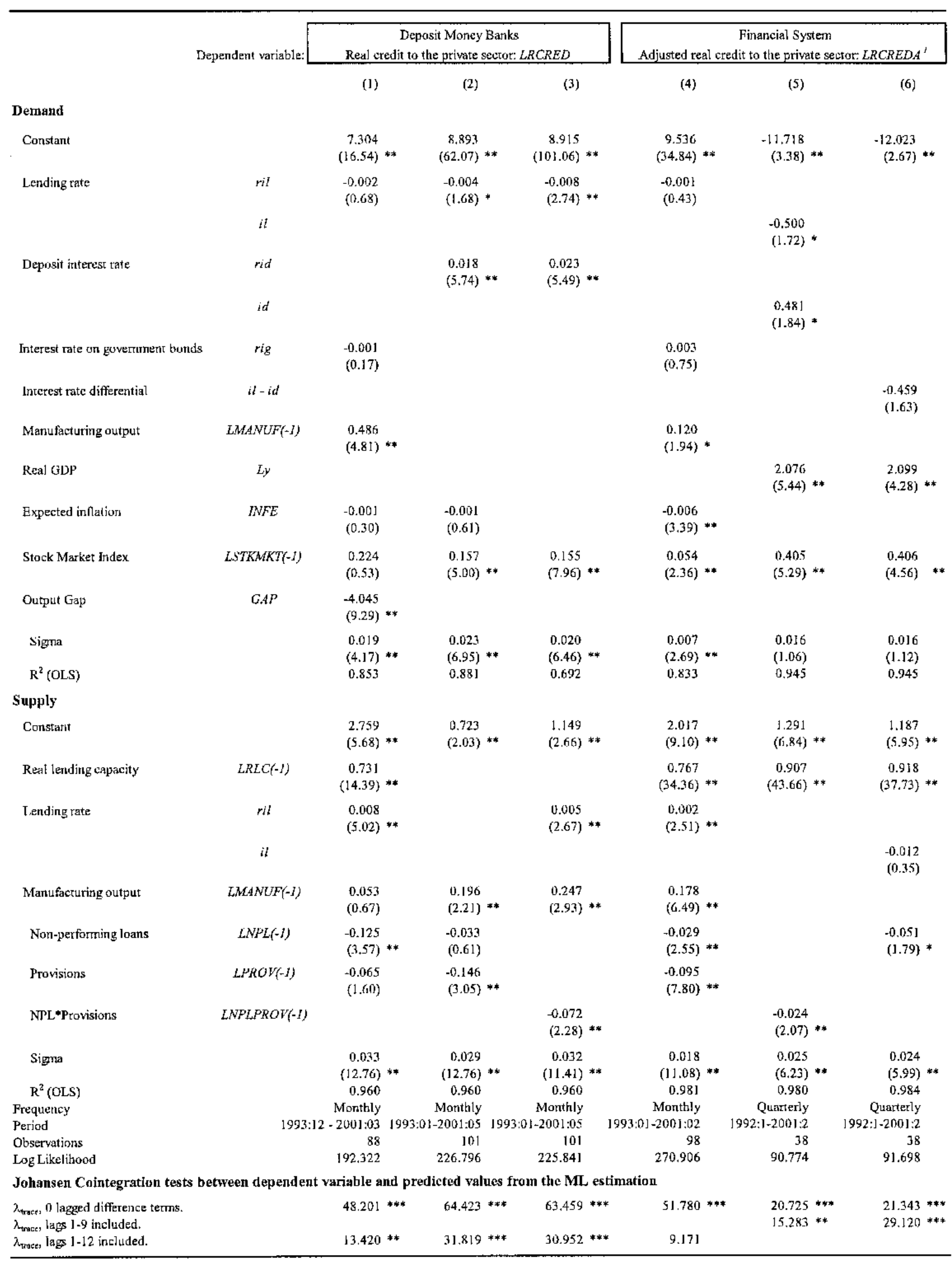

Notes: $t$-statistics shown in parentheses. Significance levels of 1 percent $\left(*^{* *}\right), 5$ percent $\left(^{* *}\right)$ and 10 percent (*) indicated. The letter $L$ at the beginning of a variable name denotes natural logarithm.

'Adjusted credit is defined as the stock of credit plus loan writc-offs. In addition, in regression (4), two small state-owned linancial institutions are excluded. 
Table 9. Mexico: Credil Demand and Supply Estimations

(Maximum likelihood disequilibrium estimation)

\begin{tabular}{|c|c|c|c|c|c|c|c|c|c|}
\hline \multirow[b]{2}{*}{ Demand } & \multirow[t]{2}{*}{ Dependent variable: } & \multicolumn{4}{|c|}{$\begin{array}{l}\text { Deposit Money Banks } \\
\text { Real credit to the private sector: } \angle R C R F D\end{array}$} & \multicolumn{4}{|c|}{\begin{tabular}{|c} 
Deposit Money Banks \\
Adjusted real credit to the private sector: $L R C R E D A^{\prime}$
\end{tabular}} \\
\hline & & (1) & & (2) & (3) & (4) & (5) & (6) & \\
\hline Constant & & $\begin{array}{r}11.329 \\
(3.09) * *\end{array}$ & & $\begin{array}{l}11.541 \\
(3.10)^{* *}\end{array}$ & $\begin{array}{l}11.481 \\
(2.87)^{* * *}\end{array}$ & $\begin{array}{l}10.920 \\
(7.07) * *\end{array}$ & $\begin{array}{l}12.403 \\
(8.66) * *\end{array}$ & $\begin{array}{l}11.877 \\
(18.65)\end{array}$ & $* *$ \\
\hline Lending rate & il & $\begin{array}{l}-0.109 \\
(-2.51)\end{array}$ & $* *$ & $\begin{array}{l}-0.106 \\
(-2.35) * *\end{array}$ & $\begin{array}{l}-0.097 \\
(1.74) *\end{array}$ & $\begin{array}{l}-0.074 \\
(-2.07) * *\end{array}$ & $\begin{array}{l}-0.062 \\
(1.58)\end{array}$ & $\begin{array}{l}-0.121 \\
(3.49)\end{array}$ & $* *$ \\
\hline EMBI price for Mexico & $E M B I$ & $\begin{array}{r}-0.009 \\
(7.90)\end{array}$ & $* *$ & $\begin{array}{l}-0.009 \\
(-7.82) * *\end{array}$ & $\begin{array}{l}-0.009 \\
(7.15) * *\end{array}$ & $\begin{array}{l}-0.006 \\
(7.53) * *\end{array}$ & $-0.006) * *$ & $\begin{array}{r}-0.006 \\
(12.39)\end{array}$ & $* *$ \\
\hline Manufacturing output & $\operatorname{LMANUF(-1)}$ & & & & & & & $\begin{array}{l}0.533 \\
(3.48)\end{array}$ & $* *$ \\
\hline Real GDP & $L y(-1)$ & $\begin{array}{r}0.429 \\
(0.81)\end{array}$ & & $\begin{array}{r}0.397 \\
(0.74)\end{array}$ & $\begin{array}{r}0.401 \\
(0.69)\end{array}$ & $\begin{array}{l}0.467 \\
(2.01) * *\end{array}$ & $\begin{array}{l}0.252 \\
(1.19)\end{array}$ & & \\
\hline Signa & & $\begin{array}{l}0.122 \\
(6.17)^{* *}\end{array}$ & & $\begin{array}{l}0.124 \\
(6.12) * *\end{array}$ & $\begin{array}{l}0.131 \\
(5.98) * *\end{array}$ & $\begin{array}{l}0.018 \\
(4.94) * *\end{array}$ & $\begin{array}{l}0.015 \\
(4.56)^{* *}\end{array}$ & $\begin{array}{l}0.018 \\
(5.48)\end{array}$ & $* *$ \\
\hline $\mathrm{R}^{2}$ (OLS) & & 0.779 & & 0.779 & 0.779 & 0.938 & 0.938 & 0.938 & \\
\hline \multicolumn{10}{|l|}{ Supply } \\
\hline Constant & & $\begin{array}{l}-2.048 \\
(0.48)\end{array}$ & & $\begin{array}{r}-0.992 \\
(0.23)\end{array}$ & $\begin{array}{r}-1.631 \\
(0.26)\end{array}$ & $\begin{array}{l}6.496 \\
(4.16) * *\end{array}$ & $\begin{array}{c}12.157 \\
(2.28)^{* *}\end{array}$ & $\begin{array}{l}6.168 \\
(3.67)\end{array}$ & $* *$ \\
\hline \multirow[t]{2}{*}{ Real lending capacity } & $L R D E P 1(-1)$ & & & & $\begin{array}{l}0.984 \\
(2.05) * *\end{array}$ & $\begin{array}{l}0.571 \\
(4.84) * *\end{array}$ & & $\begin{array}{r}0.586 \\
(4.82)\end{array}$ & ** \\
\hline & LRDEP2(-1) & $\begin{array}{c}0.951 \\
(3.06)^{* *}\end{array}$ & & $\begin{array}{l}0.867 \\
(2.84) * *\end{array}$ & & & $\begin{array}{l}0.116 \\
(0.29)\end{array}$ & & \\
\hline Lending rate & il & $\begin{array}{l}0.102 \\
(0.29)\end{array}$ & & $\begin{array}{l}0.718 \\
(5.70) * *\end{array}$ & $\begin{array}{l}0.479 \\
(5.98) * *\end{array}$ & $\begin{array}{l}0.057 \\
(1.81)^{*}\end{array}$ & $\begin{array}{l}0.102 \\
(2.74)^{* *}\end{array}$ & $\begin{array}{l}0.074 \\
(1.51)\end{array}$ & \\
\hline Interest rate on government bonds & ig & $\begin{array}{r}0.635 \\
(1.56)\end{array}$ & & & & & & & \\
\hline Non-performing loans & $L N P L(-1)$ & $\begin{array}{l}0.153 \\
(2.58)\end{array}$ & & $\begin{array}{c}0.134 \\
(1.78)\end{array}$ & $\begin{array}{l}0.106 \\
(1.66) *\end{array}$ & $\begin{array}{l}-0.014 \\
(7.64) * *\end{array}$ & $\begin{array}{r}-(0.013 \\
(8.87)\end{array}$ & $\begin{array}{r}-0.012 \\
(10.24)\end{array}$ & ** \\
\hline Dununy $^{2} * \mathrm{NPL}$ & $D 9501 * L N P L(-1)$ & $\begin{array}{l}-0.158 \\
(-2.69)\end{array}$ ** & & $\begin{array}{l}-0.138 \\
(1.85)\end{array}$ & $\frac{-0.105}{(1.67)} *$ & & & & \\
\hline Provisions & $\operatorname{LPROV}(-1)$ & & & & & $\begin{array}{c}-0.027 \\
(10.18)^{* *}\end{array}$ & $\begin{array}{l}-0.024 \\
(8.87) * *\end{array}$ & $\begin{array}{r}-0.026 \\
(10.44)\end{array}$ & ** \\
\hline Sigma & & $\begin{array}{l}0.067 \\
(5.94) * *\end{array}$ & & $\begin{array}{l}0.067 \\
(6.01)^{* *}\end{array}$ & $\begin{array}{l}0.067 \\
(5.59)^{* *}\end{array}$ & $\begin{array}{l}0.020 \\
(3.19)^{* *}\end{array}$ & $\begin{array}{l}0.022 \\
(5.63) * *\end{array}$ & $\begin{array}{c}0.014 \\
(3.34)\end{array}$ & $* *$ \\
\hline $\begin{array}{l}\mathrm{R}^{2} \text { (OLS) } \\
\text { Period }\end{array}$ & & 0.837 & 19 & $\begin{array}{c}0.836 \\
3: 12-2000: 1\end{array}$ & 0.836 & 0.962 & $\begin{array}{c}0.954 \\
1997: 02-2001:\end{array}$ & $5^{0.962}$ & \\
\hline $\begin{array}{l}\text { Period } \\
\text { Observations }\end{array}$ & & 85 & & 85 & 85 & 52 & 52 & 52 & \\
\hline Log Likelihood & & 86.308 & & 84.795 & 80.781 & 137.46 & 136.05 & 142.13 & \\
\hline \multicolumn{10}{|c|}{ Johansen Cointegration tests between dependent variable and predicted values from the ML estimation } \\
\hline \multicolumn{10}{|l|}{ Null hypothesis: no cointegration } \\
\hline$\lambda_{\text {sace, }} 0$ lagged difference tenns. & & 15.218 & ** & $13.306 * *$ & 10.561 & $39.598 * * *$ & $27.913^{* * * *}$ & $50.675 *$ & \\
\hline$\lambda_{\text {trace, }}$ lags $1-12$ included. & & 15.498 & ** & $16.305^{* *}$ & $15.140^{* *}$ & $17.957 * * *$ & $15.220 * *$ & $32.866 *$ & \\
\hline
\end{tabular}

Notes: t-statistics shown in parentheses. Significance levels of Ipercent (***), 5 percent $(* *)$ and 10 percent $(*)$ indicated.

The letter $L$ at the beginning of a variable name denotes natural logarithm.

'Defined as the stock of credit plus adjustments to incorporate private sector loan restructuring programs beginning in mid-1995.

${ }^{2}$ This durtrny variable takes a value of zero up until 1994:12, and then unity therealter, thus testing for a structural change after the credit expansion period. 
- 36 -

Table 10. Peru: Credit Demand and Supply Estimations

(Maximum likelihood disequilibrium estimation)

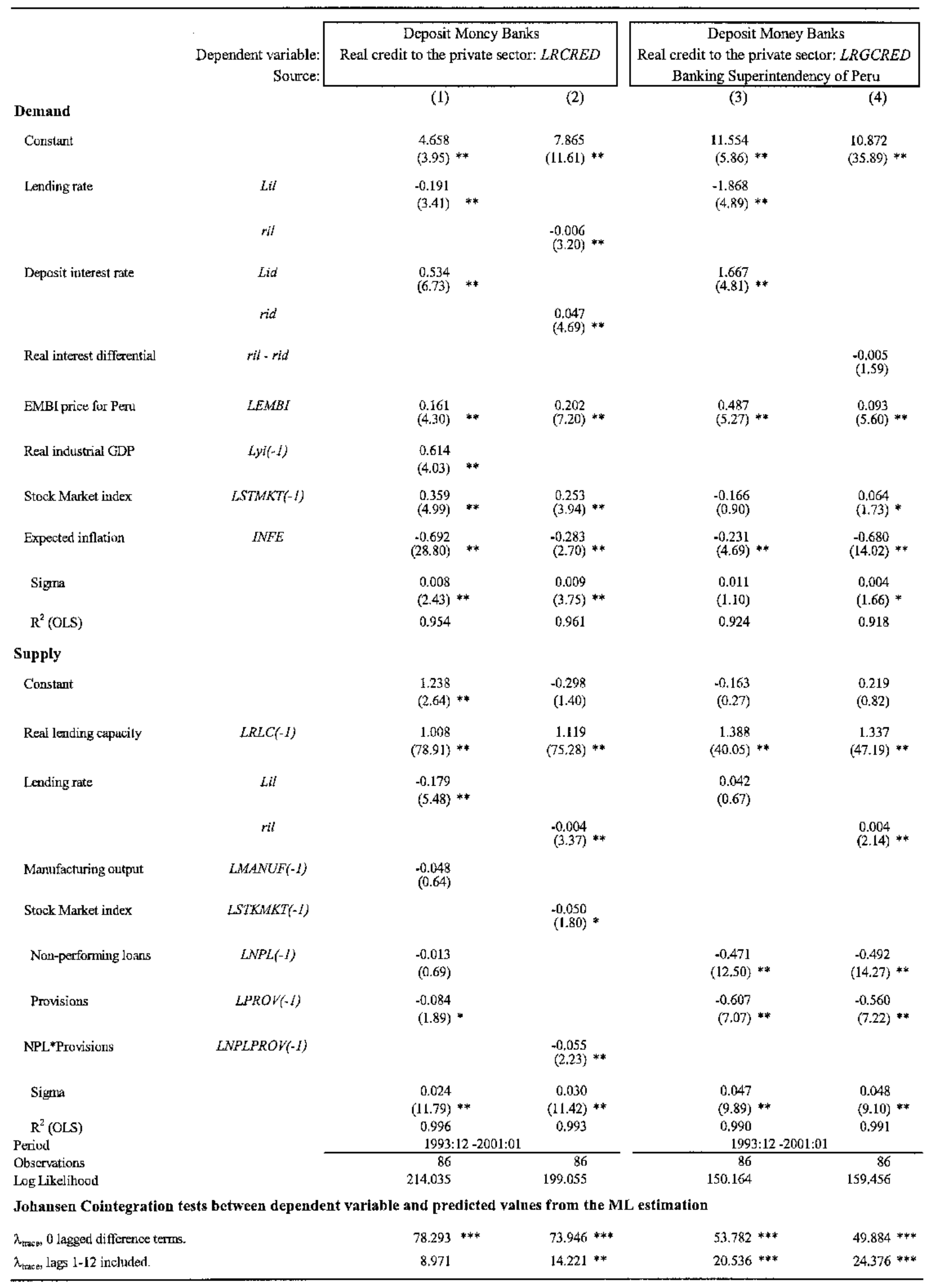

Notes: t-statistics shown in parentheses. Significance levels of 1 percent $\left({ }^{* * *}\right), 5$ percent $\left({ }^{* *}\right)$ and 10 percent $\left({ }^{*}\right)$ indicated. The letter $\mathrm{L}$ at the beginning of a variable name denotes natural logarithm. 
All estimations yield some common results. Various measures of macroeconomic conditions appear to be significant in the supply and demand functions. In particular, lagged manufacturing output is positively related to both supply and demand in all monthly estimations, and real GDP is positively related to loan demand in the quarterly estimations. The stock market index appears to reflect present and future economic conditions, rather than equity finance as a substitute for bank credit, thus its coefficient in the demand function is positive and significant across monthly and quarterly estimations. The output gap exhibits a negative coefficient, similarly to the result obtained by Ghosh \& Ghosh for Indonesia, and may reflect the fact that firms increase (decrease) their demand for external financing over own resources in bad (good) times. Since this variable was only available for a shorter time period, we excluded it from all but regression (1). The deposit interest rate performed better than the government interest rate as a proxy for the opportunity cost of bank credit from the demand side. As the deposit rate increased relative to the lending rate, it tended to have a positive impact on credit demand. Finally, in all estimations, lending capacity ${ }^{29}$ was positively and significantly related to credit supply, with an elasticity approaching unity in the quarterly regressions.

Some differences also arise across equations. Expected inflation tended to be slightly negatively related to credit demand, but only exhibited a large t-statistic in regression (4), a monthly estimation for adjusted financial system credit. Monthly estimations are noticeably better at capturing the sensitivity of demand and supply to real or nominal lending interest rates. In particular, lending interest rates were rarely significant in the supply function when using quarterly data, and the results for other variables tended to improve when this variable was excluded from the supply equation. Finally, although the measures of credit risk and regulation always exhibited the expected negative sign in the supply function, both were rarely significant at the same time. However, the interaction variable $\left(N P L^{*} P R O V\right.$ or, the ratio of loan-loss provisions to total loans) was negative and significant throughout, thus showing that a combination of credit risk and regulatory power had a negative impact on the willingness of banks to provide credit.

\section{Mexico}

A similar exercise was undertaken for the case of Mexico. There are important differences with respect to the Colombian estimations. On the one hand, as we discussed above, we included JP Morgan's EMBI price as an explanatory variable in the demand function. This allows us to test whether, following the 1995 "tequila crisis," greater availability of foreign financing permitted the Mexican private sector to grow in spite of severe problems in the financial sector. If this is the case, then we would expect a negative coefficient in the demand function; as the index increases, foreign financing becomes more easily available and, other things constant, demand for credit from domestic banks should go down.

${ }^{29}$ We defined lending capacity as the sum of bank deposits net of reserves in the case of the financial system, and plus foreign liabilities in the case of deposit money banks. 
A second difference has to do with problems of data availability. We were unable to assemble the data set for the period prior to 1993. Many variables, including those that proxy for macroeconomic conditions were not available. For the post-1993 period, there are variables for which more than one source is available.

In Table 9 we report six different estimations, for two different time periods, using two different dependent variables. For regressions (1)-(3), in which the dependent variable is the stock of private credit from deposit money banks as reported by the IFS, we use monthly data for 1993.12 to 2000.12 . This time period allows us to capture part of the pre-1995 lending boom as well as the subsequent downturn. For regressions (4)-(6), we undertake a similar adjustment as in the case of Colombia, using a series constructed by the Banco de Mexico which incorporates the effect of two major private debt restructuring programs, ${ }^{30}$ one which consists of a partial write off of bank debts funded by the government, while the other consists of a government purchase of nonperforming loans. ${ }^{31}$ The time period is 1997.02-2001.05, and thus includes only the downturn phase for bank credit in Mexico. In most estimations, we have used real GDP in order to proxy for aggregate macroeconomic conditions. Since GDP is available quarterly, we have used the same real GDP level for each month within the quarter. In the last estimation, (6), we used the monthly index of manufacturing production.

There are two sources of data for nonperforming loans. The first, which we used in regressions (1)-(3), was obtained from the World Bank. This series is quarterly, and was available from 1992:12 to 2000:12. Monthly series for both nonperforming loans and the loan-loss provisions were obtained from the Banco de México, but were available only starting in 1997:01, so they were used in regressions (4)-(6).

In all six estimations, the EMBI price appears to be negatively and significantly related to credit demand, the reflecting the degree of substitution for Mexican firms between domestic and foreign financing. As expected, demand for loans is negatively related with the lending interest rate, and the respective coefficient is statistically significant in all but one estimation. Finally, the demand for financial sector loans is positively associated with economic activity, either proxied by real GDP or manufacturing output. However, this association is significant only in two of the six estimations reported.

${ }^{30}$ The specific name given to this series is: "financiamiento total al sector privado, considerando cartera asociada a programas de reestructuras," or total financing to the private sector, considering loans related to restructuring programs.

31 This adjustment addresses to some extent the concern that, as a result of government interventions in the banking system, the decline in private sector credit as seen from balance sheets of banks overestimates the true credit contraction actually experienced by the private sector. To the extent that debts were restructured and refinanced, and in several instances directly removed from banks balance sheets and transferred to collecting agencies, the balance sheet tends to overstate the decline in credit. 
Regarding the supply of bank loans, in general it is associated in a positive and statistically significant manner with lending capacity, which we defined in two alternative ways: $D E P 1$, equal to the sum of demand, time and foreign currency deposits, and $D E P 2$, which also includes money market funds. ${ }^{32}$ As expected, the supply of loans depends positively on the interest rate on loans, and most of the regressions yielded a statistically significant coefficient.

We attempted to capture the opportunity costs of alternative uses of bank funds, by including the interest rate on government paper ( $\mathrm{ig}$ ) in the supply function. We obtain a positive, albeit not statistically significant, coefficient. The best estimations were obtained when ig was not included.

Regarding loan quality, the two groups of regressions shown in Table 9 must be interpreted separately. For the longer period (regressions (1)-(3)) we use the quarterly World Bank nonperforming loans data, and are unable to control for provisions. We also interacted $N P L$ with a dummy variable equal to zero until the end of 1994 and equal to 1 afterwards, so as to test for the possibility that regulation and supervision became tighter-and thus bank behavior became more sensitive to credit risk - after the financial crisis of late 1994 and early 1995.

Our results are consistent with a significant shift in bank behavior after the 1994 crisis. Prior to 1995, the supply of loans to the private sector was positively associated with the level of $N P L$. One possible interpretation of this result is that, in the context of a weak regulation, banks were probably "gambling for resurrection," increasing their supply of credit when credit risk was rising. Following the crisis, and given that we cannot reject the hypothesis that the sum of the coefficients of $N P L$ and of the interactive variable $\left(D 9501^{*} N P L\right)$ is equal to zero, this type of adverse behavior would have ceased. Note, however, that according to this group of regressions, we do not obtain the expected negative relationship between credit supply and $N P L$, not even in the post-crisis period.

The results reported in regressions (4)-(6) of Table 9 seem much more comforting. For the shorter, post-crisis period, and using the redefined version of credit, in all three estimations we consistently obtain negative and statistically significant coefficients both for nonperforming loans as well as for provisions. As was mentioned above, unfortunately we were unable to obtain data on provisions for the period prior to 1997.

\section{Peru}

The regression results for Peru are shown in Table 10, which we divide into two pairs of regressions according to the credit series used. In regressions (1) and (2) we use the IFS series for credit to the private sector by deposit money banks, and in regressions (3) and (4) we use

\footnotetext{
${ }^{32}$ Contrary to both the Colombian and Peruvian cases, throughout our study period Mexican banks were not subject to reserve requirements, therefore we did not subtract reserves from deposits to obtain lending capacity, since held reserves would be essentially voluntary and thus endogenous to banks' lending decisions.
} 
Peru's central bank series for gross credit by banks to the private sector. The main difference between the two is that the latter registers a more pronounced decline starting in early 1999.

Several differences emerge with respect to the other two countries analyzed. First, the Peruvian case appears to be the only one in which expected inflation is a consistently significant variable explaining demand for credit. Private agents in Peru appear to extract more information about macroeconomic conditions from the evolution of inflation. Second, in contrast to the case of Mexico, the $E M B I$ is now positively related to credit demand, presumably because it reflects macroeconomic conditions more than it captures the private sector's ability to obtain financing abroad. Third, especially in regressions (1) and (2), credit demand is affected significantly by a wider set of macro indicators. Finally, for the IFS series used in the first two regressions, it proved very difficult to arrive at a supply function that exhibited the expected positive sign for the lending interest rate. While this may be related to the high degree of dollarization of bank activities in Peru which makes it difficult to construct an appropriate lending interest rate covering both domestic and foreign currency operations, ${ }^{33}$ it remains a puzzle. However, it must also be noted that this problem was reduced considerably when switching to the Peruvian Banking Superintendency series ${ }^{34}$ in regressions (3) and (4).

We also observe some results that are common to those of Colombia and Mexico. Lending capacity-defined as in the Colombian case-was a major determinant of credit supply. Credit risk and/or regulation factors also proved to be relevant for credit supply, and in regressions (3) and (4), both are significant at the same time.

\section{E. Decomposition of Estimated Changes in Credit}

Based on selected regression results from Tables 8-10, we decomposed the predicted changes in supply and demand for credit, contrasting the expansion and slowdown periods in each of the countries. We concentrated on the predicted shifts in the supply and demand curves, excluding all changes brought about as a result of adjustment in interest rates. We grouped changes in supply under three major headings: macroeconomic conditions (stock market index, manufacturing output, and real GDP), lending capacity, and risk/regulation factors (NPL, $P R O V$, or their interaction variable). In each case, the estimated change was defined as the coefficient multiplied by the change in the respective explanatory variable throughout the given expansion or slowdown period. For example, the estimated change attributable to NPL in Colombia during the expansion would be equal to its coefficient (for example, -0.05 in the

${ }^{33}$ The regressions reported use domestic currency deposit and lending interest rates. We also ran regressions using foreign currency interest rates, but there was no improvement and, in many cases, the results were worse. A possible alternative may be to construct average implicit interest rates from the balance sheet and earnings statements of banks.

34 The main difference between the two is that the IFS series, "claims on the private sector," includes investments, while the Banking Superintendency (SBS) series does not. To the extent that banks substituted away from credit and forward investments in recent years, the IFS series would tend to understate the decline in credit. 
quarterly regression (6) multiplied by the change in NPL from 1992:1 to 1997:4). The results of the decomposition exercise are shown in Table 11.

Observing the components of changes in the supply curve, it is apparent that in all countries the expansion and slowdown periods were very different. With the exception of Peru, where improving loan quality contributed substantially to the expansion, in all the other countries lending capacity explained well over 90 percent of the expansion. ${ }^{35}$ During the slowdown, however, in all countries the combination of credit and regulatory tightening contributed to a reduced willingness to lend. In fact, in Peru this effect appears to offset completely a continued expansion in lending capacity in recent years.

The dominant role played by the availability of loanable funds in Colombia, particularly during the credit expansion period, is also related to the role played by capital inflows intermediated by the domestic financial system. In Figure 5 we show the evolution of the capital account balance and total financial credit to the private sector, both expressed as a percentage of GDP. For the 1990-2000 period, the two variables are highly correlated.

On the demand side, a similar asymmetry arises between the two phases. Improving macroeconomic conditions provided the key stimulus for credit growth in all countries during the expansion, and in Mexico a tightening in access to foreign financing - as reflected in a deteriorating EMBI price-reinforced this effect. However, only in the case of Colombia did a subsequent deterioration in macroeconomic conditions have a noticeable adverse impact on credit demand. In Mexico and Peru, macroeconomic indicators in fact continued to improve, although the in the case of Mexico this effect was overwhelmed by an increase in access to foreign financing, as shown by the large negative effect of $E M B I$ on credit demand.

Finally, comparing the size of the shifts in the supply and demand curves may permit us to assess the degree of tightness in the credit markets in these three countries. According to our econometric results, in Colombia supply of credit by commercial banks (DMB) greatly outpaced demand during the expansion, primarily due to a relative abundance of loanable funds undoubtedly brought on in part by deregulation undertaken early in the decade, which reduced certain advantages that other intermediaries had acquired over banks in previous years. However, when taking the financial sector as a whole, the opposite appears to hold, with economic growth pushing demand faster than the rate at which supply was growing. During the slowdown, the shifts in supply and demand curves were roughly equivalent, thus requiring relatively small adjustments in interest rates. In Mexico, the credit market appears to have been tight at the end of the expansion, with demand having grown more rapidly than supply, but this situation was reversed during the slowdown; although credit supply did contract owing to a deceleration in lending capacity and increasing credit risk and regulatory strictness, the major

\footnotetext{
${ }^{35}$ Note that the adverse "gambling for resurrection" behavior, while statistically significant, was quantitatively small in the Mexican case, where its estimated impact did not register at two digits.
} 
Table 11. Decomposition of Estimated Changes in Real Credit

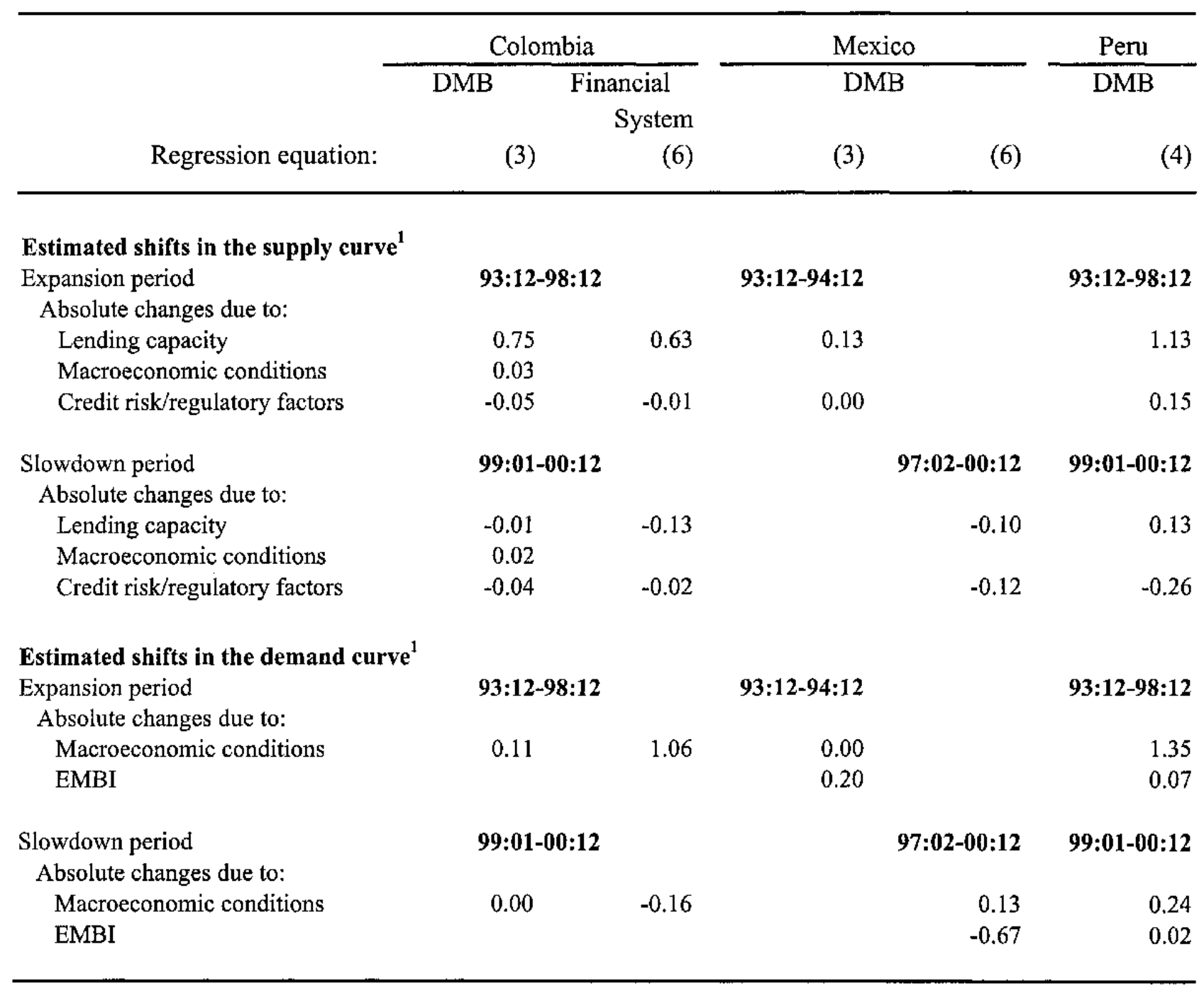

Source: Tables 8-10, and data sources for estimation.

${ }^{1}$ The total changes are equal to the estimated change in the dependent variable, the natural logarithm of real credit to the private sector. For both supply and demand, we exclude changes attributable to the lending and alternative interest rates in order to focus on shifts in the curves. 
Figure 5. Colombia. Credit and Capital Inflows

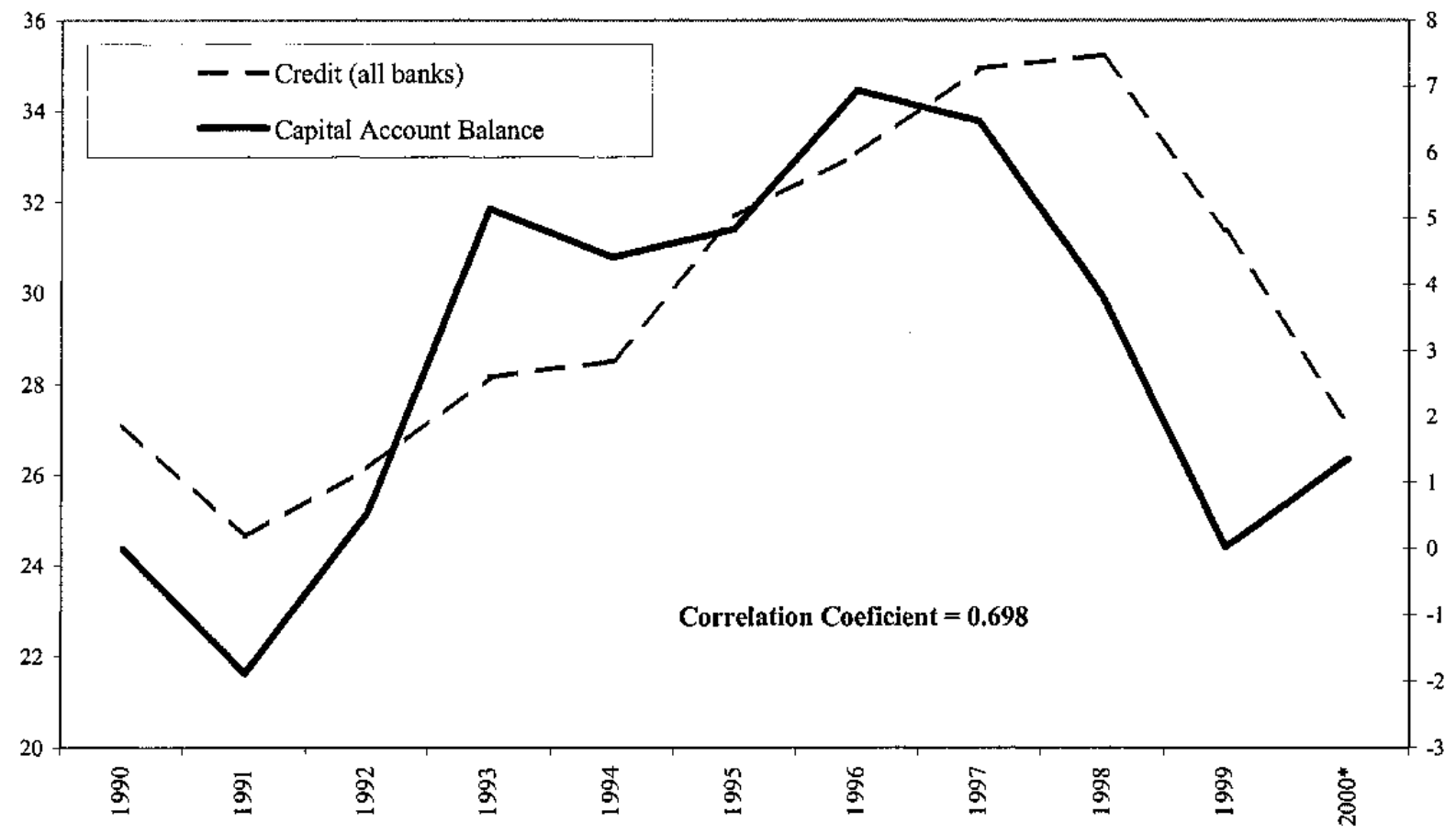

impact was on the demand side. Peru exhibited pronounced accelerations of roughly the same size in demand and supply during the expansion, but appears to have entered a period of increased credit tightening; while demand has continued to grow, supply in recent years has remained stagnant as a result of decreased willingness to lend.

\section{Conclusions}

Several Latin American countries have experienced substantial slowdowns in credit to the private sector, which in several instances has followed episodes of "credit booms." As we showed in Section III, while the early slowdowns of Venezuela and Chile qualify as credit busts, the most recent slowdowns still do not. However, the earlier experience in the region, as well as that of other regions of the world suggest that credit slumps can be quite protracted. In that sense, it is certainly possible that the current slowdown might be signaling the beginning of a long period of sluggish private sector credit. The latest figures for 2001 certainly confirm that credit continues to decline in real terms in most of the countries analyzed.

Our analysis of balance sheets shows that the evolution of deposits is by far the dominant factor both in the credit expansion and slowdown stages. Interestingly, this dominant effect 
tends to be much stronger during the expansion period. In fact, almost the entire expansion of credit can be ascribed to an increase in loanable funds, in many instances associated with capital inflows. While the decline in loanable funds is also important in explaining credit slowdowns, other factors come into play, thus the structure of balance sheets changed considerably in the Latin American countries examined, particularly during the most recent period.

Econometric estimations for Colombia, Mexico, and Peru are also reported. Our estimations exhibit some results that are common to previous studies: macroeconomic conditions significantly affect credit demand and sometimes credit supply, lending capacity plays a key role in determining credit supply, and certain alternative interest rates have a significant effect on credit demand. However, we also introduced two additional sets of variables not included in previous studies and which we suspected would be important determinants of credit supply or demand. On the one hand, we incorporated credit risk and regulatory variables in the supply function, and found that at least one was significant in each of the countries. Second, we incorporated the EMBI price for Mexico and Peru, finding that in the former case it reflected substitution by borrowers from domestic to foreign sources, while in the latter case it provided an additional signal on the macroeconomic environment.

Our estimation approach allowed us to decompose the shifts in supply and demand curves during the expansion and slowdown periods in each of the three countries. Confirming the findings of our examination of bank balance sheets, we saw on the supply side that the expansions were driven primarily by lending capacity, or loanable funds, while the risk and regulatory variables became key during the slowdown. On the demand side, the expansion was characterized by improvements in macroeconomic conditions across all countries, while in the slowdown only Colombia exhibited a clear impact of deteriorating conditions on credit demand. In Mexico, access to foreign funds appeared to be the dominant factor, and in Peru demand has appeared to continue its upward path in recent years. Finally, our results also served to highlight key differences in the nature of the credit slowdown in the three countries. In Colombia, with the most modest contraction of the three, supply and demand shifts are roughly similar. In Mexico, the situation appears to be one of excess supply, while the results for Peru point to possible excess demand for credit in recent years. 


\section{IFS Banking System Definitions}

\begin{tabular}{|c|c|c|c|}
\hline & Deposit Money Banks & Other Banking Institutions & Nonbank Financial Institution \\
\hline Argentina & $\begin{array}{l}\text { National, Provincial, and } \\
\text { Municipal Banks, Caja Nacional } \\
\text { de Ahorro (savings bank), and } \\
\text { private commercial banks, } \\
\text { including branches of foreign } \\
\text { banks. }\end{array}$ & $\begin{array}{l}\text { Investment Finance Companies, Credit } \\
\text { Cooperatives, and Savings and Loan } \\
\text { Associations for housing. }\end{array}$ & \\
\hline Bolivia & $\begin{array}{l}\text { Commercial Banks and the State } \\
\text { Bank. From Dec. } 1996 \text { on, also } \\
\text { includes specialized banks. }\end{array}$ & $\begin{array}{l}\text { Specialized banks, up to Dec. } 1996 \text {. From Dec. } \\
1996 \text { on: Savings and Loan Associations, } \\
\text { Savings and Credit Cooperatives, and financial } \\
\text { funds. }\end{array}$ & \\
\hline Brazil & $\begin{array}{l}\text { Commercial Banks, Bank of } \\
\text { Brazil, multiple banks, Federa] } \\
\text { Savings Bank, and State Savings } \\
\text { Bank. }\end{array}$ & $\begin{array}{l}\text { Investment Banks, National Bank for Economic } \\
\text { and Social Development, state development } \\
\text { banks, finance and investment companies, } \\
\text { housing credit companies. From Dec. } 1996 \text { on, } \\
\text { also includes mortgage companies. }\end{array}$ & $\begin{array}{l}\text { Leasing companies, stock } \\
\text { brokerage houses, and } \\
\text { distributor companies. }\end{array}$ \\
\hline Chile & $\begin{array}{l}28 \text { Commercial Banks and Banco } \\
\text { del estado (government-owned). }\end{array}$ & 1 Finance company. & 8 Pension Funds. \\
\hline Colombia & $\begin{array}{l}\text { Commercial banks. From Dec. } \\
1994 \text { on, also includes Central } \\
\text { Mortgage Bank. }\end{array}$ & $\begin{array}{l}\text { Savings and Housing Corporations, Financial } \\
\text { Corporations (investment banks), Financial } \\
\text { Cooperative Institutions, Central Mortgage } \\
\text { Bank, FEN, Bancoldex, FINAGRO, } \\
\text { FINDETER, FONADE. From Dec. } 1994 \text { on, } \\
\text { excludes National Mortgage Bank. From Nov. } \\
1998 \text {, also includes FOGAFIN. }\end{array}$ & \\
\hline México & \multicolumn{2}{|c|}{ Banking Institutions: Commercial Banks and FSM Development Bank. } & \\
\hline$\overline{\text { Perú }}$ & $\begin{array}{l}\text { Bank of the Nation, private } \\
\text { commercial banks. }\end{array}$ & 5 development banks, under liquidation. & \\
\hline Venezuela & Commercial and Universal Banks & $\begin{array}{l}\text { Workers' Bank, mortgage banks, National } \\
\text { Savings and Loan, investment banks. From } 1994 \\
\text { on: excludes Workers' Bank. From } 1996 \text { on: } \\
\text { includes Financial Leasing Companies, and } \\
\text { investment funds. }\end{array}$ & \\
\hline
\end{tabular}

Notes: IFS denotes the IMF's International Financial Statistics. 
Selected Latin American Countries: Private Sector Credit Nonbank/Bank Credit

\begin{tabular}{|c|c|c|c|c|c|c|}
\hline & \multicolumn{5}{|c|}{ (percentage) } & \multirow{2}{*}{$\begin{array}{r}\text { Oct. } \\
2001\end{array}$} \\
\hline & 1985 & 1991 & 1994 & 1996 & 2000 & \\
\hline \multirow[t]{2}{*}{ Chile: Nonbank Financial Institutions } & 0.17 & 24.34 & 31.75 & 22.68 & 14.09 & .. \\
\hline & 1998 & & & & & \\
\hline Brazil: Nonbank Financial Institutions & 8.23 & 1.20 & 1.12 & 1.52 & 3.95 & $\ldots$ \\
\hline \multicolumn{7}{|l|}{ Mexico } \\
\hline Savings and Loan Institutions & $\ldots$ & $\ldots$ & $\ldots$ & 0.23 & 0.33 & 0.39 \\
\hline All nonbank ${ }^{1}$ & $\ldots$ & $\ldots$ & $\ldots$ & 9.73 & 17.67 & 26.74 \\
\hline
\end{tabular}

Sources: International Financial Statistics, Banco de Mexico website.

${ }^{1}$ Includes savings and loan institutions, securities holdings of investment societies, and investments of stock brokerage houses. 


\section{REFERENCES}

Agenor, Pierre Richard, Joshua Aizenman, and Alexander Hoffmaister, 2000, "The Credit Crunch in East Asia: What Can Bank Excess Liquid Assets Tell Us?" NBER Working Paper No. 7951 (Cambridge, Massachusetts: National Bureau of Economic Research).

Arbelaez, Maria A. and Juan J. Echavarria, 2002, "Investment and Financial Constraints in the Colombian Manufacturing Sector," mimeo, Fedesarrollo.

Barajas, Adolfo, Enrique López, and Hugo Oliveros, 2001, "Por Qué en Colombia el Crédito al Sector Privado es Tan Reducido?" Borradores Semanales de Lconomía No. 185 (Bogotá: Banco de la República).

Bernanke, Ben S. and Alan S. Blinder, 1988, "Is It Money or Credit, Or Both, Or Neither?" AEA Papers and Proceedings.

Bernanke, Ben S. and Cara S. Lown, 1991, "The Credit Crunch," Brookings Papers on Economic Activity, Vol. 2, pp. 205-247.

Berróspide, José and José Dorich, 2001, "Aspectos Microeconómicos de la Restricción Crediticia en el Perú: 1997-2000,” mimeo, Banco Central de Reserva del Perú.

Blaschke, Winfrid, Matthew Jones, Giovanni Majnoni and Soledad Martinez Peria, 2001, "Stress Testing of Financial Systems: An Overview of Issues, Methodolgies, and FSAP Experiences," IMF Working Paper No. WP/01/88 (Washington: International Monetary Fund).

Borensztein, Eduardo and Jong-Wha Lee, 2000, "Financial Crisis and Credit Crunch in Korea: Evidence from Firm-Level Data," IMF Working Paper No. WP/00/25 (Washington: International Monetary Fund).

Braun, Matías and Ricardo Hausmann, 2001, "Financial Dvelopment and Credit Crunches: Latin America and the World," mimeo, Harvard University.

Braun, Miguel and Eduardo Levy-Yeyati, 2000, "The Role of Banks in the Transmission of Shocks: Micro Evidence from Argentina 1996-1999," (Unpublished: Buenos Aires: Universidad Torcuato Di Tella).

Carrasquilla, Alberto, Arturo Galindo, and Diego Vásquez, 2000, "El Gran Apretón Crediticio en Colombia: una Interpretación," Coyuntura Económica.

Catão, Luis, 1997, "Bank Credit in Argentina in the Aftermath of the Mexican Crisis: Supply or Demand Constrained?" IMF Working Paper WP/97/32.

Ding, Wei, Ilker Domac, and Giovanni Ferri, 2000, "Is There a Credit Crunch in East Asia?" (Unpublished: Washington: World Bank). 
Galindo, A. and A. Micco, 2001, "Creditor Protection and Financial Cycles," IADB Working Paper No. 443 (Washington: Inter-American Development Bank).

Ghosh, Atish R. and Swati R. Ghosh, 1999, "East Asia in the Aftermath: Was There a Crunch?” IMF Working Paper No. WP/99/38 (Washington: International Monetary Fund).

Gourieroux, Christian, 2000, Econometrics of Qualitative Dependent Variables, (Cambridge: Cambridge University Press).

Gourinchas, Pierre-Olivier, Rodrigo Valdés, and Oscar Landerretche, 2001, "Lending Booms: Latin America and the World," NBER Working Paper No. 8249 (Cambridge, Massachusetts: National Bureau of Economic Research).

Kim, Hyun E., 1999, "Was Credit Channel a Key Monetary Transmission Mechanism Following the Recent Financial Crisis in the Republic of Korea?" World Bank Policy Research Working Paper No. 2103 (Washington: World Bank).

Krueger, A. and A. Tornell, 1999, "The Role of Bank Restructuring in Recovering from Crises: Mexico 1995-98,” NBER Working Paper No. 7042 (Cambridge, Massachusetts: National Bureau of Economic Research).

Laffont, J-J. and R. Garcia, 1977, "Disequilibrium Econometrics for Business Loans," Econometrica, Vol. 45 (July).

Maddala, G.S., 1983, Limited-Dependent and Qualitative Variables in Econometrics (Cambridge: Cambridge University Press).

Misas, Martha and Enrique López Enciso, 2001, "Desequilibrios Reales en Colombia," Borradores de Economía, No. 181 (Bogotá: Banco de la República).

Pazarbasioglu, Ceyla, 1997, "A Credit Crunch? Finland in the Aftermath of the Banking Crisis," IMF Staff Papers, Vol. 44 No. 3, pp. 315-327.

Peek, Joe and Eric Rosengren, 1995, "Bank Regulation and the Credit Crunch," Journal of Banking and Finance, Vol. 19, pp.679-692.

Romer, C. and D. Romer, 1990, "New Evidence on the Monetary Transmission Mechanism," Brookings Papers on Economic Activity (1).

Sealey, C.W., 1979, "Credit Rationing in the Commercial Loan Market. Estimates of a Structural Model Under Conditions of Disequilibrium," Journal of Finance. Vol. 34, pp. 689-702.

Steiner, Roberto and Natalia Salazar, 1998, "Perspectivas de los Inversionistas Institucionales en Colombia," mimeo, Fedesarrollo.

Woo, David, 1999, "In Search of 'Capital Crunch': Factors Behind the Credit Slowdown in Japan,” IMF Working Paper No. WP/99/3 (Washington: International Monetary Fund). 